University of Chicago Law School

Chicago Unbound

Journal Articles

Faculty Scholarship

2000

\title{
The Adolescent's Stake in the Allocation of Educational Control between Parent and State
}

Emily Buss

Follow this and additional works at: https://chicagounbound.uchicago.edu/journal_articles

Part of the Law Commons

\section{Recommended Citation}

Emily Buss, "The Adolescent's Stake in the Allocation of Educational Control between Parent and State," 67 University of Chicago Law Review 1233 (2000).

This Article is brought to you for free and open access by the Faculty Scholarship at Chicago Unbound. It has been accepted for inclusion in Journal Articles by an authorized administrator of Chicago Unbound. For more information, please contact unbound@law.uchicago.edu. 


\title{
The Adolescent's Stake in the Allocation of Educational Control Between Parent and State
}

\author{
Emily Buss $\dagger$
}

\begin{abstract}
Courts, policymakers, and scholars have long struggled with the question of how to allocate educational control between parents and the state, particularly where parents' preferences are religiously motivated. While the debate reflects a broad range of viewpoints, these viewpoints share $a$ common blind spot: They focus on the state's interest in imparting certain knowledge and skills, and ignore the state's interest in facilitating interactions among ideologically diverse peers. This Article argues that, particularly for older adolescents, the nature of their peer interactions has a far bigger impact on their development than does the content of their curriculum. Drawing on the psychological literature of child development, this Article suggests that exposing these older adolescents to ideologically unlike peers will facilitate identity development that best balances their interest in maintaining a sense of affiliation with their parents' religious community, on the one hand, and their interest in exercising autonomy in the making of important choices, on the other. This Article raises questions about the appropriateness of home schooling and even private religious schooling in the late teenage years, and considers measures short of prohibiting such forms of education that might encourage ideological mixing among older adolescents.
\end{abstract}

Legislatures, courts, and scholars have long debated the proper allocation of educational authority between parent and state, and the debate has proved particularly contentious when parental claims of control are rooted in religious beliefs. Yet despite the apparent diversity of viewpoints on vouchers, home schooling, early school withdrawal, and the like, the courts and political theorists addressing these issues share a common blind spot: They focus on the substance of the curriculum in question and ignore the effect educational choices have on children's interactions with one another.

In the context of adolescents' education, this singular focus on substance is misplaced, for the acquisition of information and academic skills plays a relatively small role in their development. What matters to adolescent development is relationships with peers, because it is largely through these relationships that they pursue the difficult and important task of identity formation - the sorting and selecting of values, beliefs, and tastes that will define their adult selves. Who those peers are and, particularly, the diversity of their convictions and attitudes, will have a significant effect on the course of that development.

$\dagger$ Assistant Professor of Law, The University of Chicago. My thanks to William Buss, Richard Epstein, Daniel Fischel, Jack Goldsmith, Robert Katz, Bret Koplow, Saul Levmore, Tracey Meares, Elaine Meyer-Lee, Martha Nussbaum, Gary Palm, Eric Posner, Stephen Schulhofer, David Strauss, Cass Sunstein, and the participants at the University of Chicago Law School's faculty workshop for their helpful comments on an earlier draft, and to Melissa Coughlin, Pratheepan Gulasekaram, Da-Wai Hu, Yael Karabelnik, and Christopher Snell for their excellent research assistance. The Arnold and Frieda Shure Research Fund and the Max Rheinstein Research Fund in Family Law provided support for this research. 
The importance of these peer interactions is not lost on parents, particularly religiously motivated parents. Indeed, an interest in controlling these interactions motivates many of the parents' educational choices and their decision to litigate, where those choices are thwarted. But the states, in identifying their educational interests, and the courts and political theorists, in balancing these interests against the contrary claims of parents, fail to acknowledge the state interest in facilitating the very interactions the parents seek to prevent. Associational control is counted only on the parents' side of the ledger, to be ceded to them whenever such control can be relinquished without compromising the state's control over minimum curricular standards.

By considering the value of children's exposure to unlike peers, this Article adds an important entry on the state's side of the ledger. My analysis draws on the psychological literature on child development, a body of knowledge largely ignored in the debate. I give particular focus to parental claims, and children's interests, in the context of religiously motivated disagreements, where the parental claims receive the greatest constitutional protection, and where the ideological focus of the disagreements is most pronounced.

In Part I, I begin by considering how lawmakers and theorists have allocated educational control between parents and the state. In the legislative context, I note an increasing willingness to cede to parents control over their children's educational associations, so long as parents satisfy the state's minimal curricular objectives. In the courts, where the parent's interest in control is frequently asserted as a constitutionally protected right of free religious exercise, the countervailing state interests are, again, cast in exclusively curricular terms. And even the political theorists, who expand upon the courts' analysis of the state interests at stake, continue to confine their discussion to curricular control. In Part II, I discuss the developmental literature's emphasis on the importance of peer interaction to the adolescent's identity formation process, and the relationship of peer and parental influences on a child's identity development. This literature suggests that affording children an opportunity to explore identity choices through peer interactions will facilitate the development of their capacity for autonomous choice, a capacity commonly thought necessary for political participation and the exercise of rights, including religious rights, in our democracy. In Part III, I consider the implications of this more sophisticated understanding of adolescent development for the promulgation of educational policy and the resolution of the problems posed by the cases. I conclude that a state interest in fostering the capacity for independent thought in its children could justify policies encouraging and even, perhaps, compelling some amount of exposure to ideologically unlike peers, and that fears that such policies might wrest 
control of upbringing, particularly religious upbringing, from parents can be minimized by limiting the reach of the policies to the oldest adolescents.

\section{THE CURRENT Discourse}

Driven by concerns about the educational quality and ideological orientation of the public schools, parents have sought increasing control over their children's education through the political process and in the courts. Policymakers have responded to these demands by ceding considerable control to parents through voucher programs, charter-school initiatives, and home-schooling options. Under all of these approaches, the state maintains some control over the curricular content of the child's education while relinquishing control over the child's peer associations. Similarly, where parents attack a state educational requirement through litigation, the state limits its defense, and the court its consideration of state interests, to curricular concerns, ignoring the interest in ideological integration that might strengthen the state's claim. Although the political theorists give considerably more attention than the courts to the question of the state's proper role as educator in our system of government, they, too, tend to think only in curricular terms. States, courts, and theorists, alike, ask what should be taught, but not with whom those lessons should be learned.

\section{A. Educational Policy Trends}

In 1983, the National Commission on Excellence in Education reported to Congress that public schools reflected a "rising tide of mediocrity that threaten[ed] our very future as a Nation and a people." At the same time, schools were coming under increasing attack by organizations associated with religious conservatives for their secular humanist teachings, ${ }^{2}$ and their promotion of "tolerance," ${ }^{3}$ which

1 National Commission on Excellence in Education, $A$ Nation at Risk: The Imperative For Educational Reform 5 (1983).

2 See David E. Anderson, National Counsel of Churches Studies Public Education, UPI (Oct 8,1983 ) (observing that "a number of churches and religious groups, especially those on the conservative end of the theological spectrum, are turning away from the public schools and their 'secular humanism"'); Robert Reinhold, Textbook Debate Broadens in Texas, NY Times A10 (Aug 3,1983) (detailing the challenges of parents against textbooks that they think promote secular humanism); Ellie McGrath, A Victory for Christian Schools, Time 66 (Jan 10, 1983) (describing the criticism of many Christian parents that the public schools teach "a godless philosophy of "secular humanism"). See also George W. Dent, Jr., Religious Children, Secular Schools, 61 S Cal L Rev 863,869-72 (1988) (cataloging the protests by religious parents against the secular beliefs that public schools teach to children).

3 See Kenneth E. Woodward and Eloise Salholz, The Right's New Bogyman, Newsweek 48 (July 6, 1981) (noting that the Reverend Jerry Falwell and other fundamentalist Christians oppose the type of "tolerance" that bumanism emphasizes in the curriculum of public schools). 
was viewed as antithetical to many religious teachings. Together, these attacks, one focused on quality and the other on content, inspired parents to demand greater control over educational choices affecting their children. ${ }^{4}$ Policymakers have been increasingly responsive to these demands, making it easier for parents to choose a different school for their child, or to pull their child out of school altogether.

Increased state support for home schooling represents the most dramatic example of this growing deference to parental control. Until fairly recently, state compulsory education laws commonly made it difficult, if not impossible, for parents to educate their children at home. While parents have long sought authority to home school their children, the demand has exploded in recent years, and states have responded with legislation and regulations that have encouraged the trend. Increasingly, states are abandoning educational requirements, such as certification, that made it difficult or impossible for parents to home school their children, and replacing such requirements with regulations designed to serve the limited purpose of ensuring that children acquire the basic knowledge and academic skills offered in school. Increasingly, states are enacting legislation that expressly rec-

4 See Neal Devins, Fundamentalist Christian Educators v. State: An Inevitable Compromise, 60 Geo Wash L Rev 818, 819 (1992) (observing that the struggle of Christian fundamentalists with state authorities over the content of education during the 1970 s and early 1980 s led to increased control by parents over the education of their children after 1983); John E. Chubb and Terry M. Moe, Politics, Markets, and the Organization of Schools, 82 Am Pol Sci Rev 1065, 106566 (1988) (listing more active parental involvement in making educational decisions as one of the consequences of the perception of decline in public schools in the 1980s); Jean Rosenblatt and Hoyt Gimlin, Tuition Tax Credits, in Hoyt Gimlin, ed, Education in America: Quality vs. Cost 11-15 (Cong Q 1981) (discussing how the rising dissatisfaction of parents with quality and content of public schools motivated a shift towards private education). See also Robert C. Bullman and David L. Kirp, The Shifting Politics of School Choice, in Stephen D. Sugarman and Frank R. Kemerer, eds, School Choice and Social Controversy 36-40 (Brookings 1999) (arguing that the concerns about educational quality and the preferences for choice fueled the movement away from public schooling); Joseph P. Viteritti, Choosing Equality 1-9 (Brookings 1999) (contending that parental focus on the quality of schools resulted in greater demand for choice in education).

5 See, for example, State v Edgington, 99 NM 715, 663 P2d 374 (NM App 1983) (concluding that a statute that expressly prohibited home schooling by excluding such arrangements from the list of permissible private schooling arrangements did not violate the Equal Protection Clause).

6 See, for example, Parr v State, 117 Ohio St 23, 157 NE 555, 556 (1927) (rejecting constitutional challenge to compulsory attendance law); State v Bailey, 157 Ind 324, 61 NE 730, 730 (1901) (rejecting parent's challenge to Indiana's compulsory attendance law as, among other things, an "inva[sion of] the natural right of a man to govern and control his own children").

7 See, for example, People v DeJonge, 442 Mich 266, 501 NW2d 127, 141 (1993) (reporting that twenty states have repealed teacher certification requirements in the past ten years); Jack MacMullan, Comment, The Constitutionality of State Home Schooling Statutes, 39 Vill L Rev $1309,1336-37$ (1994) (reporting that as recently as 1983 roughly half of the states did not permit home schooling, whereas all states now allow home schooling under certain circumstances).

8 See MacMullan, Comment, 39 Vill L Rev at 1347-48 (cited in note 7) (noting that standardized testing and the review of teaching materials constitute two primary means employed by states to assess the appropriateness of home-schooling programs). 
ognizes parents' right to home school, or at least allows home schooling, so long as home schoolers provide an "equivalent education," or

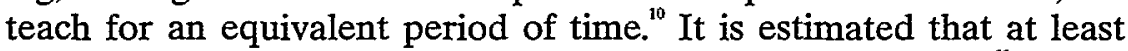
one million children are currently being educated at home, "where parents are able to maintain tight control over their children's peer associations.

Policymakers have also begun experimenting with voucher programs that allow a parent to shift some portion of the public educational dollars allocated to her child to a non-public school. ${ }^{12}$ There is some variation in the types of schools covered by the programs, but all voucher programs limit inclusion to schools deemed to meet minimal curricular standards. ${ }^{13}$ In contrast, particularly where the program authorizes the application of vouchers toward tuition at a sectarian school, ${ }^{14}$ the program clearly facilitates the parents' control over their

9 See id at 1341 (reporting that thirty states now expressly exempt home-schooled children from the compulsory atttendance laws).

10 Id at 1338 (reporting that thirteen states allow an exemption from the compulsory attendance laws for children receiving "equivalent instruction," and describing equivalency in substantive terms).

11 See Louise Yarnall, Where the Kitchen is Also the Classroom, NY Times G1 (Oct 29, 1998) (noting that the estimates of the number of home-schooled children range from 1 million to 1.6 million, and stating that the numbers have tripled in the past decade).

12 In the past decade, nearly half the states have proposed voucher legislation, see Danielle Jess Latham, Note, Wall of Separation or Path to Interaction: The Uncertain Constitutional Future of School Vouchers in Light of Inconsistent Developments in Judicial Neutrality Between Church and State, 48 Drake L Rev 403, 405 (2000), and a few have begun to experiment with implementation. See id at 411-14 (describing voucher programs in Milwaukee and Cleveland). For a general overview of the status of voucher programs in the United States, see Martha M. McCarthy, What is the Verdict on School Vouchers?,81 Phi Delta Kappan 371 (Jan 2000) (reviewing the progress of school voucher programs in various cities and states).

13 See, for example, Ohio Rev Code Ann \$ 3313.976(A)(3) (Baldwin 1999) (requiring private schools receiving voucher money to meet "all state minimum standards for chartered nonpublic schools"); Wis Stat $\S 119.23$ (1999) (itemizing minimum standards that private schools participating in Wisconsin's voucher program must meet). Some states require approval before private schools can become eligible to be part of any voucher program. See 20-A Me Rev Stat Ann $\$ 5204$ (1999) ("Secondary students whose parents reside in a unit which neither maintains a secondary school nor contracts for secondary school privileges may attend a private school approved for tuition purposes."); 16 Vt Stat Ann \$ 824(b) (Equity 1999) (ordering school districts to pay the full tuition charged by certain private schools when the pupil is a resident of the school district).

14 The various states differ as to whether their voucher programs include parochial or sectarian schools. Wisconsin, Ohio, and Florida allow vouchers to be used for religious private schools. See Simmons-Harris v Zelman, 72 F Supp 2d 834, 835-39 (N D Ohio 1999) (noting that the Cleveland voucher experiment included funding for parochial and sectarian schools); Jackson $v$ Benson, 218 Wis 2d 835, 578 NW2d 602, 607-11 (1998) (describing how the Milwaukee school choice program allowed parents to use vouchers for religious schools). Maine and Vermont limit the use of school vouchers in their states to non-religious private schools. See Bagley v Raymond School Department, 728 A2d 127, 130-31 (Me 1999) (remarking that Maine does not allow voucher money to be used towards religious private education); Chittenden Town School District v Department of Education, 738 A2d 539, 542-44 (Vt 1999) (observing that parents cannot use school vouchers in Vermont to pay for parochial or sectarian schools). 
children's association with ideologically diverse peers. The selection of a religious school matches the child not only with a religiously grounded curriculum, but also with peers whose parents have chosen to point them in the same ideological direction.

A growing number of states and localities are also embracing the charter-school movement as another means of improving educational quality through interschool competition and enhanced parental control over school placement. ${ }^{15}$ Charter school initiatives make it possible for private entities to develop their own schools and to draw down public dollars to educate students whose parents choose to enroll them in the schools. Like voucher and home-schooling programs, charter-school initiatives impose certain substantive performance criteria on the new schools, ${ }^{16}$ and unlike the other approaches, these initiatives sometimes require that the racial proportions in the charter schools match those in the public schools to prevent charter schools from becoming sites for de facto segregation. ${ }^{17}$ Not surprisingly, however, none of these initiatives requires ideological diversity in these charter schools, despite the fact that parental authority will predictably be exercised in some instances to produce ideological segregation. This ideological segregation could be by design, or simply an inadvertent product of parents' reliance on information about like-minded parents' choices in making their own educational decisions.

\footnotetext{
Voucher programs that include religious schools have been subject to Establishment Clause challenges, with mixed results. Compare Simmons-Harris, 72 F Supp 2d at 834 (enjoining implementation of voucher program on Establishment Clause grounds), with Jackson, 578 NW2d at 602 (finding that inclusion of sectarian schools in voucher program did not violate the Establishment Clause). Commentary on the constitutionality of such voucher programs is similarly mixed. See, for example, Marci A. Hamilton, Power, the Establishment Clause, and Vouchers, 31 Conn L Rev 807 (1999) (arguing that vouchers would disturb the balance of power between church and state, making them unconstitutional); Michael W. McConnell, Governments, Families, and Power: A Defense of Educational Choice, 31 Conn L Rev 847 (1999) (arguing that voucher programs that include religious schools are constitutional); Mark Tushnet, Will ContextDependent Balancing Do the Job We Want Done?, 31 Conn L Rev 861 (1999) (agreeing with Professor Hamilton's constitutional conclusion while questioning her method of analysis); Marc D. Stern, School Vouchers: The Church-State Debate That Really Isn't, 31 Conn L Rev 977 (1999) (agreeing with Professor Hamilton's opposition to vouchers, but disagreeing with her assesment of the Founders' views towards religion).

15 The first legislation authorizing charter schools was enacted in Minnesota in 1991, and by 1998 , at least thirty states authorized the operation of charter schools with public support. See Kevin S. Huffman, Note, Charter Schools, Equal Protection Litigation, and the New School Reform Movement, 73 NYU L Rev 1290, 1293 (1998).

16 See id at 1295 (noting that continued public funding for charter schools is tied to performance measures).

17 See Fla Stat $\$ 228.056(6)(c)(4)$ (1999) (requiring charter schools to "achieve a racial/ethnic balance reflective of the community" they serve); SC Code Ann $\$ 59-40-50$ (B)(6) (Law Co-op 1999) (forbidding the racial composition of charter schools to differ from the racial composition of public schools by more than 10 percent); Wis Stat $\$ 118.40(4)(b)(2)$ (1999) (prohibiting charter schools from discriminating on the basis of race, sex, religion, national origin, and ancestry among others).
} 
All three of these educational reforms maintain state control over minimal curricular standards while relinquishing control over peer associations to parents. Accordingly, by increasing parents' control over their children's educational placements, these programs are likely to restrict children's opportunities to mix with peers whose upbringing is grounded in different values and beliefs. Further exacerbating this result, some of these choice-enhancing policies are tied to prohibitions on extracurricular mixing: students whose parents choose to educate them at home or in a nonpublic charter school are sometimes expressly prohibited from participating in after-school athletic programs. ${ }^{18}$ The primary focus of this Article is to consider the cost, to children, of this ideological separation.

\section{B. The Cases}

Where educational requirements do not comport with parental viewpoints, parents frequently challenge those requirements through litigation. If the parents' objections are not religiously motivated, their challenges are grounded in the substantive due process right of parental control over the education and upbringing of their children. These secular challenges rarely succeed. ${ }^{19}$ More successful, however, are par-

18 See, for example, Nev Rev Stat \& 386.560(4)-(5) (1999) (allowing charter-school students to participate in limited public school extracurricular activities, but not in any after-school athletic activities); SC Code Ann \$59-40-50(9)(c)(3) ("The sponsor shall have no obligation to provide extracurricular activities or access to facilities of the school district for students enrolled in the charter school."). See also Gallery v West Virginia Secondary Schools Activities Commission, 205 W Va 364, 518 SE2d 368 (1999) (dismissing as moot case challenging law excluding homeschooled children from participation in interscholastic athletics); Bradstreet $v$ Sobol, 225 AD2d 175, 650 NYS2d 402 (1996) (upholding school district's exclusion of home-schooled child from interscholastic sports program against due process and equal protection challenges by the child and her mother); Davis v Massachusetts Interscholastic Athletic Association, 1995 Mass Super LEXIS 791 (enjoining athletic association and school district from excluding home-schooled child from athletic participation). But see Swanson v Guthrie Independent School District No. I-I, 942 F Supp 511 (W D Okla 1996) (finding that school district's refusal to allow a home-schooled child to attend public school part-time did not violate the parents' free exercise rights). Not all states exclude home-schooled and charter-schooled children from extracurricular programs. See, for example, Cal Educ Code $\$ 8482.3$ (West 1999) (allowing charter-school students to share after-school activities with public school students); 1999 Colo Rev Stat \$ 22-32-116.5(2)(b) ("If a student's school of attendance or nonpublic home-based educational program does not offer an activity in which the student wishes to participate, the student may participate in the activity at another public school in the student's school district of attendance or in the student's school district of residence."); $24 \mathrm{~Pa}$ Cons Stat Ann $\$ 17-1719-\mathrm{A}$ (Purdon 1999) ("[N]o school district of residence shall prohibit a student of a charter school from participating in any extracurricular activity of that school district of residence.").

19 See Null v Board of Education, 815 F Supp 937, 940 (S D W Va 1993) (concluding that the substantive due process right of a parent to direct the education of her children is a "general liberty interest subject to reasonable state regulation"); Clonlara, Inc v Runkel, 722 F Supp 1442, 1457 (E D Mich 1989) (holding that, where parents have no religious basis for their claim of a right to home school their children, they are appropriately subject to reasonable government regulations). 
ents who object to educational requirements on religious grounds, arguing that the requirements in question also violate their First Amendment right of free religious exercise. Both because parental claims receive the greatest constitutional protection in this context, and because religiously motivated claims are most consistently framed in ideological terms, I will focus on these challenges in discussing the courts' consideration of parents' constitutional claims for educational control.

In resolving cases in which parents seek to exempt their children from a state's educational requirements by asserting their constitutional right to control their children's religious upbringing, ${ }^{21}$ courts ask whether the challenged state requirement burdens genuine religious practice or belief, and if it does, whether the requirement is narrowly tailored to serve a compelling state interest. The test itself is relatively uncontroversial, in large part because it gives no direction about how to evaluate the burdens and interests in question, leaving resolution to a case-by-case application.

The structure of the test is significant, however, in one respect: It vests the claim against the state with the parent, who is not the intended subject of the state's intervention. ${ }^{23}$ In this sense, the right is exceptional. It is the right to control another's access to state benefits. While some theorists have taken the position that affording parents such rights is constitutionally suspect because it protects parents' interests at the expense of their children's, ${ }^{24}$ the predominant view, which

20 See Employment Division, Department of Human Resources of Oregon $v$ Smith, 494 US 872,881 (1990) (noting that the parental interests in Yoder were afforded special protection because they implicated both free exercise rights and parental rights under the Due Process Clause).

21 The right to an exemption is asserted under the Free Exercise Clause of the First Amendment and the Due Process Clause of the Fourteenth Amendment. The Court has recently explained that it is only the combination of the religious exercise right with the right of parental control over upbringing that entitles parents to exemptions from facially neutral requirements. See Smith, 494 US at $881-82$.

22 Many of these cases also assert the free exercise claims of children, but it is the parents' claims that the courts address in their decisions. This is surely due, in part, to the lack of clarity about the nature and extent of children's constitutional rights in this area, and the lack of perceived need to resolve this uncertainty in the context of these cases where the children's claims mirror those of the parents. Even if children are assumed to have rights coextensive with those of adults, however, the Court's decision in Smith suggests that a religious objection to a state's facially neutral educational requirement would not justify an exemption if not accompanied by a claim of a due process right of parental control. Id at 872 .

23 The parent is, however, often the party held responsible for failing to ensure the child's participation. See, for example, Wisconsin v Yoder, 406 US 205 (1972) (reviewing constitutionality of convictions of Amish parents for failing to send their children to school after the eighth grade); Pierce $v$ Society of Sisters, 268 US 510 (1925) (considering Oregon law requiring parents to send their children to public school and authorizing fines or imprisonment for failure to do so).

24 See James G. Dwyer, Religious Schools v. Children's Rights 136-40 (Cornell 1998) (argu- 
I share, is that considerable deference to parents on matters of religious upbringing serves children's interests overall, and can be justified so long as the effects of this deference are at worst neutral for children.

Children are generally perceived as ill-prepared to make good judgments about their own interests, ${ }^{26}$ and therefore the law looks for the best surrogates to act on their behalf. Parents are thought to be especially well qualified to act in their children's interests because they feel a deep emotional attachment to their children and know their needs well. ${ }^{27}$ The state, in contrast, seems an especially poor candidate to act on children's behalf on matters of religious upbringing, both because the Establishment Clause prohibits the state from making such religious judgments and because the state lacks any expertise in the particular needs of individual children. Although the test tips the balance heavily toward the parent, it does not resolve all claims for the parent. The compelling state interest inquiry recognizes that it is appropriate to consider what lies on the other side of the balance, to consider what benefits the state educational requirement offers, both for the children involved and for society as a whole. ${ }^{23}$

Even where the state's interest in enforcing the requirement is focused exclusively on its effects on the child in question, the court

ing that protecting parents' rights at the expense of their children's rights violates the Equal Protection Clause of the Fourteenth Amendment).

25 See, for example, Stephen G. Gilles, Hey, Christians, Leave Your Kids Alone!, 16 Const Commen 149 (1999) (reviewing Dwyer's Religious Schools v. Children's Rights). To say that vesting the right to control religious upbringing in parents serves children's interests is not to say that these are the only interests served by this allocation of rights. In asserting this right of control, parents clearly also serve their own interests, see Yoder, 406 US at 209 (noting that the Amish "believed that by sending their children to high school, they would not only expose themselves to the danger of the censure of the church community, but ... also endanger their own salvation and that of their children"), and the interests of their religious community. See id at 212 (referring to expert testimony suggesting that sending children to high school would "ultimately result in the destruction of the Old Order Amish church community as it exists in the United States today"). Neither of these interests, I contend, would be sufficient to justify vesting control of the child in the parent if these interests were believed to run contrary to the child's own interests.

26 Whether they are in fact ill-prepared to identify their own interests, and, if so, at what ages and under what circumstances, is an important, underdiscussed issue that exceeds the scope of this Article.

27 Consider William Blackstone, 1 Commentaries on the Laws of England 435 (Chicago 1979) ("The municipal laws of all well-regulated states have taken care to enforce this duty [to support one's children]: though providence has done it more effectually than any laws, by implanting in the breast of every parent that natural ... insuperable degree of affection, which not even ... the wickedness, ingratitude, and rebellion of children, can totally suppress or extinguish.").

28 See Prince v Massachusetts, 321 US 158, 165 (1944) ("Against these sacred private interests, basic in a democracy, stand the interests of society to protect the welfare of children ....It is the interest of youth itself, and of the whole community, that children be both safeguarded from abuses and given opportunities for growth into free and independent well-developed men and citizens."). 
might reject a parent's claim of right to an exemption if it concluded that recognizing the exemption would be harmful to the child. ${ }^{29}$ In such a case, the court would need to balance the gains to the child from enforcing the requirement against the loss associated with depriving the parent of control. Where the court concludes that third party interests are at stake, intervention may be appropriate even where the individual child's interests would be best served by deferring to parental control. This Article considers, primarily, the proper allocation of authority between parent and the state in serving the interests of a particular child. As I will note briefly in the final section, the child's interest in interaction with unlike peers will naturally be mirrored in the interest those unlike peers have in interacting with her, and therefore a child-specific consideration of interests inevitably expands to encompass the interests of third-party peers.

Where only the individual child's interests are at stake, the constitutional test can be seen as a means of balancing the claims of two surrogates, each asserting authority to act on the child's behalf. In determining whether a parent is entitled to an exemption, the court is indirectly deciding whether the child will be at least as well off under the control of the parental surrogate. The assessment is indirect because the parental rights conception of the protection takes away the courts' authority to make case-specific inquiries about whether the parent is making the best possible choices for her child. Instead, courts make a more generalized judgment about whether the value of deferring to parents for this sort of decisionmaking is counterbalanced by state educational interests. Since the right at stake is grounded in large part in a conception of children's interests, and the countervailing interests of the state are focused on the same children, any "balancing" should assess the relative weight to be afforded these two sorts of child-focused interests.

In the end, the test provides courts with no assistance in determining whether a state has a strong enough interest in controlling the relevant aspect of a child's education to overcome the traditional deference shown to parents. This assessment of the nature and strength of the state interests at stake is left to the courts in their application of the test to the specific cases before them. In my discussion of these cases, which follows, I will argue that the courts have overlooked the importance of peer interactions to children's development, particularly in their teenage years. In focusing exclusively on the substance of

29 See id at 166 ("[T]he family itself is not beyond regulation in the public interest, as against a claim of religious liberty .... Acting to guard the general interest in youth's well being, the state as parens patriae may restrict the parent's control by requiring school attendance, regulating or prohibiting the child's labor and in many other ways.") (citations omitted). 
the school curriculum in question, the courts take inadequate account of the state's interest in facilitating children's interactions with peers.

1. Pierce $v$ Society of Sisters.

In 1925, the Supreme Court held in Pierce $v$ Society of Sisters ${ }^{30}$ that a state could not require all children to attend public (rather than private) schools. ${ }^{31}$ Although the suit was brought by two corporations that ran schools whose economic survival was threatened by the mandatory public school law, the case now stands as one of two pillars upholding the well recognized due process right of parents to "direct the upbringing and education of children under their control." ${ }^{, 33} \mathrm{De}$ claring that "those who nurture ... and direct [a child's] destiny have the right, coupled with the high duty, to recognize and prepare him for additional obligations," the Court hinted at the benefit to children that flows from deferring to parental control."

While the particular holding in Pierce is now taken for granted, its implications are tremendous. Whatever the state can do to control the content of classroom instruction, ${ }^{35}$ the state cannot control with whom children are educated. Parents are given authority over their children's school associations, particularly along ideological lines, ${ }^{36}$ and may prevent them from reaping the benefits that might come from mixing with unlike peers. ${ }^{37}$ Pierce was decided on due process rather

30268 US 510 (1925).

31 The Oregon statute in question made it a misdemeanor, subject to fines or imprisonment, for a parent to fail to send his children to public school between the ages of eight and sixteen. See id at 530 .

32 The other pillar, Meyer v Nebraska, 262 US 390 (1923), was brought, on due process grounds, by a teacher who was convicted for teaching German to a ten-year-old child, in violation of Nebraska's prohibition against the teaching of foreign languages to children in the first eight grades of school.

33 Pierce, 268 US at 534-35.

34 Id at 535 (emphasis added). But see Barbara Bennett Woodhouse, "Who Owns the Child?": Meyer and Pierce and the Child as Property, 33 Wm \& Mary L Rev 995, 1112-13 (1992) (arguing that the conception of parental rights enshrined in Meyer and Pierce "had a strong property component").

35 Two years after the Pierce decision, the Court made clear that this authority over content was also circumscribed by the Constitution. Farrington $v$ Tokushige, 273 US 284 (1927) (finding that an act regulating content in private foreign language schools violated due process).

36 In Runyon v McCrary, 427 US 160, 178-79 (1976), the Court recognized a narrow exception to the parent's authority to control her child's associations in the school setting. The Court upheld Congress's authority, under $\$ 2$ of the Thirteenth Amendment, to outlaw racial discrimination in private school admissions. As in Pierce, no free exercise claims were pressed in Runyon.

37 Barbara Bennett Woodhouse describes the common schooling movement that was partly responsible for the enactment of Oregon's universal public schooling law. See Woodhouse, 33 Wm \& Mary L Rev at 995, 1017-21 (cited in note 34). In her historical discussion, she focuses on the movement's aims of assimilation and the creation of a common, unified citizenry. My focus, in contrast, is on the potential for an integrated educational setting to produce greater diversity. 
than free exercise grounds, and subsequent decisions suggest that the Constitution affords only limited protection to parental claims motivated by purely secular concerns. ${ }^{38}$ The Court has, however, clearly interpreted the Constitution to afford parental claims grounded on religious convictions the highest level of protection, a level of protection greater even than that afforded to religious claims asserted by individuals outside of their parental role.

\section{Wisconsin v Yoder.}

The case most clearly establishing this principle, and most influencing courts' analysis of parents' religiously based challenges to state educational requirements, is Wisconsin v Yoder, ${ }^{40}$ which upheld the right of Amish parents to remove their children from school two years shy of the age mandated by Wisconsin's compulsory attendance law. In Yoder, the parents explicitly sought, among other things, to prevent contact between their children and non-Amish peers. ${ }^{41}$ Unlike in grade school, where children attended local Amish schools or local public schools whose students were predominantly Amish, ${ }^{42}$ requiring high school attendance would have forced the Amish children to learn alongside significant numbers of non-Amish peers. Forcing this exposure against the parents' wishes, the Court concluded, would impose a significant burden on the parents' exercise of their religion through the control of their children's religious upbringing.

In considering what state interests lie on the other side of the constitutional balance, however, the Court took no account of the potential value Amish students might derive from interactions with nonAmish peers in high school. Instead, the Court engaged in a relatively hollow inquiry that appeared to be about curricular content: the Court emphasized that the basic skills of reading, writing, and arithmetic

38 See Wisconsin v Yoder, 406 US 205, 215 (1972) ("A way of life, however virtuous and admirable, may not be interposed as a barrier to reasonable state regulation of education if is based on purely secular considerations."). While the Court in Yoder cites to the Pierce decision with approval, its analysis raises some question about whether a purely secular form of the right recognized in Pierce survives. The interests in Pierce, of course, can easily be recast in religious terms, but a court could arguably conclude that a parent's purely secular interest in sending her child to a private school was no longer protected after Yoder.

39 See Employment Division, Department of Human Resources of Oregon $v$ Smith, 494 US $872,881-82$ (1990) (recognizing special protections for free exercise claims that implicate parental rights).

$40 \quad 406$ US 205 (1972).

41 See id at 211 (noting that "[f]ormal high school education beyond the eighth grade is contrary to Amish beliefs, not only because it places Amish children in an environment hostile to Amish beliefs .... and with pressure to conform to the styles, manners, and ways of the peer group, but also because it takes them away from their community, physically and emotionally, during the crucial and formative adolescent period of life").

42 See id at 217. 
were already secured in grades one through eight, argued that the value of two additional years would be slight, ${ }^{43}$ and noted the comparative advantage of the hands-on vocational skills training the Amish receive. These considerations all suggest that the Court was thinking only about the usefulness of the substance of a high school education. Even this curricular assessment was shaped by the Court's deference to the parents' associational choices. Because the parents intended that these children would grow up to be part of an Amish community, the Court reasoned, the two additional years of study, while surely important for other children, were unnecessary for the Amish children.

The two related themes found in Yoder reappear throughout the cases in this area: (1) Courts afford tremendous deference to parents' choices about their children's current and future associations, and (2) courts limit their consideration of potential countervailing state interests to curricular (rather than associational) concerns. Before considering the developmental implications of this analysis, I will review some of the contexts in which these themes appear.

\section{Home schooling.}

Parents who seek to educate their children at home are generally seeking control over both the substance of their children's education ${ }^{45}$ and the nature of their children's peer interactions. ${ }^{45}$ As already noted, states have moved rapidly in recent years to remove regulatory barriers to home schooling. Where parents encounter such barriers, they have frequently challenged them in litigation. While there is some evidence in earlier cases that courts took account of the developmental

43 This point, and its focus on content, is expressed more clearly in Justice White's concurrence, in which he notes the appropriateness of a state's substantive educational standards and explains that the exemption requested is appropriate "[s]ince the Amish children are permitted to acquire the basic tools of literacy to survive in modern society by attending grades one through eight and since the deviation from the State's compulsory-education law is relatively slight." Id at 238 (White concurring).

44 Id at 222 (majority) ("It is one thing to say that compulsory education for a year or two beyond the eighth grade may be necessary when its goal is the preparation of the child for life in modern society as the majority live, but it is quite another if the goal of education be viewed as the preparation of the child for life in the separated agrarian community that is the keystone of the Amish faith.").

45 See, for example, Duro v District Attorney, Second Judicial District of North Carolina, 712 F2d 96, 97 (4th Cir 1983) (listing, among reasons for home schooling, the parents' desire to protect children from secular humanist teachings and to eschew medical treatment).

46 See, for example, State v Patzer, 382 NW2d 631, 633 (ND 1986) (noting that parents' desire to home school was tied, in part, to their fear of negative peer influences, which would prevent children from acquiring the right religious values and achieving salvation); Duro, $712 \mathrm{~F} 2 \mathrm{~d}$ at 97 (listing, among reasons for home schooling, the parents' desire to shield their children from exposure to different religious beliefs and corrupting influences). 
cost to children of depriving them of peer interactions, such concerns are not expressed in more recent decisions.

In analyzing the state's interests in regulating home schooling, the courts now focus exclusively on substantive issues. The courts uphold mandatory achievement tests because these tests allow the state to assess whether children are learning sufficient information and skills." "Equivalency" requirements are also found appropriate, interpreted as they now are to assess curricular rather than interactive equivalence." Teacher certification requirements get a more mixed reception, ${ }^{50}$ because they are not as clearly tied to the substance of the curriculum. Courts that strike down certification requirements point to the lack of clear linkage between certification and the quality of teaching, and courts that have upheld them point to the specialized training and experience in teaching they reflect. The general message from the courts is that parents have a right to control their children's associations by keeping them out of school, so long as they ensure that they learn the information and skills required to function in society as adults.

47 Knox v O'Brien, 72 A2d 389, 392 (NJ Super 1950) (concluding that home schooling did not provide the required "equivalent" education of the public schools because it did not offer the same opportunities for social interaction but rather "cloister[ed] and shelter[ed]" children).

48 See Murphy v Arkansas, 852 F2d 1039 (8th Cir 1988) (upholding standardized tests for home-schooled children against constitutional challenge); Care and Protection of Charles, 399 Mass 324, 504 NE2d 592, 602 (1987) (noting that superintendent, in overseeing home schooling program, may require standardized testing to "ensure educational progress and the attainment of minimum standards").

49 See, for example, Blount v Department of Educational and Cultural Services, 551 A2d $1377,1384-85$ (Me 1988) (finding that the requirement that a home-schooling program be preassessed to ensure that it provided "equivalent instruction" was the least restrictive means of meeting the state's compelling interest in ensuring that children received a quality education). See also Battles v Anne Arundel County Board of Education, 904 F Supp 471 (D Md 1995) (upholding requirement of state monitoring of content of home-schooling program); Care and Protection of Charles, 504 NE2d at 601-02 (noting that superintendent, in assessing whether homeschooling program is "equal "in thoroughness and efficiency," should focus on "the proposed curriculum and the number of hours of instruction in each of the proposed subjects," but may not dictate "the manner in which the subjects will be taught"); Matter of Falk, 110 Misc 2d 104, 441 NYS2d 785, 789 (NY Fam Ct 1981) (concluding that state's Education Law requires no instruction "designed to enhance a student's learning experience by the free association with other children in the classroom, on the athletic field or on the bus," but rather asks only "whether [the child's parents] have furnished a substantially equivalent instruction in twelve specific subject areas as that afforded in the public schools").

50 Compare People v DeJonge, 442 Mich 266, 501 NW2d 127, 144 (1993) (determining that a teacher certification requirement was unnecessary to meet the state's legitimate goal of ensuring that children are educated for self-sufficiency and political participation), with Patzer, 382 NW2d at 631,633 (determining that a teacher certification requirement was narrowly tailored to meet the state's interest in providing children with an education adequate to prepare them to undertake the responsibilities of citizenship). 


\section{Specific curricular objections.}

Inspired by the broad protection afforded in Yoder, many parents have sought to assert some control over their children's education by asserting free exercise objections to their children's exposure to specific ideas, ${ }^{51}$ texts, ${ }^{52}$ or activities ${ }^{53}$ in the public schools. Unlike in Pierce, Yoder, and the home-schooling cases, these parents do not seek to control the peers with whom their children interact, and their curricular objections are often narrowly crafted. ${ }^{\text {s4 }}$ Despite the relative modesty of their requests, however, courts often deny these parents' curriculum-specific challenges. ${ }^{35}$ Having ceded their authority to control their children's associations to the state by sending them to public school, parents find there is little left of their right to control their children's education in that setting.

The disparate protection courts afford to curricular and associational objections plays out in the courts' analyses of the religious burden imposed in the two contexts. In Yoder and the home-schooling cases, courts often find that requiring the objectionable exposure would impose serious burdens on the parents' religious exercise. In the context of curricular challenges, in contrast, the courts downplay the burden associated with the objectionable exposure. ${ }^{\text {st }}$ The difference appears to be one of degree: Compelled exposure when the entire school experience offends is construed as burdensome, whereas compelled exposure when only pieces of the curriculum offend is construed as acceptable.

51 See, for example, Brown v Hot, Sexy and Safer Production, Inc, 68 F3d 525, 529 (1st Cir 1995) (challenging school's requirement that plaintiff children attend an assembly that included crude sexual gestures and remarks).

52 See, for example, Mozert v Hawkins County Board of Education, 827 F2d 1058 (6th Cir 1987) (challenging required reading of texts parents found offensive to their religious beliefs).

53 See, for example, Curtis v School Committee of Falmouth, 420 Mass 749,652 NE2d 580 (1995) (challenging condom distribution in the schools).

54 See, for example, Brown, $68 \mathrm{~F} 3 \mathrm{~d}$ at 529 (challenging attendance requirement at a single assembly); Curtis, 652 NE2d at 580 (seeking authority only to restrict the access of their children to condoms without their consent). Note that the parents' claims are not always narrowly limited to a request for a child-specific exemption to particular material. In some cases, the parents seek to eliminate objectionable material from the curriculum altogether. See Grove v Mead School District No. 354, 753 F2d 1528, 1531 (9th Cir 1985) (objecting, on free exercise grounds, to the inclusion of a book in high school English program, despite receiving permission to opt out of the reading and discussion); Smith v Ricci, 89 NJ 514, 446 A2d 501, 503 (1982) (objecting to "familylife education program" that included education on human sexuality, despite the fact that parents were allowed to excuse their children from objectionable parts of the curriculum).

55 See, for example, Mozert, $827 \mathrm{~F} 2 \mathrm{~d}$ at 1070 (denying challenge to textbooks offensive to plaintiffs' religious beliefs); Brown, 68 F3d at 525 (denying challenge to students' compelled attendance at a sexually explicit AIDS awareness assembly); Curtis, $652 \mathrm{NE2d}$ at 580 (denying challenge to condom distribution program).

56 See, for example, Curtis, 652 NE2d at 587 (noting that mere offensive exposure is not enough to invoke free exercise protection).

57 In Mozert, 827 F2d at 1067, the court conceded that in Yoder, too, the parents' goal was 
Setting to one side the analytic problems with this distinction, ${ }^{38} \mathrm{I}$ note here its effect: While not expressed in these terms, the effect of the courts' analysis is to find that requirements interfering with parental control over peer associations impose heavy burdens on religious exercise (and therefore can only be justified by a compelling state interest), whereas requirements that interfere with parental control over content impose insignificant burdens (and therefore are not subject to constitutional constraints). ${ }^{59}$ Indeed, in the leading case of Mozert $v$ Hawkins County Board of Education, ${ }^{60}$ the court even suggests that part of the reason exposure to curricular specifics in public school cannot be said to impose unconstitutional burdens is that the parents always have the option of removing their children altogether and educating them in a private religious school or home-school setting. ${ }^{61}$ The message of these cases is clear: States are to be given broad discretion in fashioning a curriculum that serves their educational purposes, but the control of children's associations is left up to their parents.

to protect their children from objectionable exposure, and focused on the issue of degree: "Unlike the plaintiffs in the present case, the parents in Yoder did not want their children to attend any high school or be exposed to any part of a high school curriculum .... [They] attempt[ed] to shield their children from all worldly influences." In contrast, the Mozert parents "want their children to acquire all the skills required to live in modern society.... [but to] have them excused from exposure to some ideas they find offensive." Id.

58 The courts' analysis in this and other similar cases might be read to suggest a distinction between a sect whose religion expressly forbids the exposure in question and one that merely forbids certain values and practices, which might be undermined, indirectly, by exposure to certain ideas. But such an interpretation is problematic. First, it probably does a disservice to parents who object to particular curricular offerings, who surely feel directed by their faith to shield their children from the troubling influences. Second, it is a slippery distinction to maintain here, where the right at issue is the right to control religious upbringing. In many faiths, the dictate is to secure the transmission of one's faith to one's children. Precisely how the parent achieves this end may be left to the parent, but the parent will certainly feel religiously compelled, even in exercising her discretion, to achieve the religiously mandated end.

I note that finding that exposure to specific texts or activities imposes a significant burden on a parent's religious exercise would not force courts to allow the requested exemptions. Rather, it would require the court to consider what lies on the other side of the balance-the state's interest in maintaining uniformity in the curriculum and exposing all students to the challenged portions. Arguing against the exemption would be the disruptive effect that the exemption would cause to the school's ability to teach other children, and even the child subject to the exemption. The distraction and time loss associated with frequent excusals and reentries, the costs of developing a parallel curriculum, and the lost opportunities for group learning processes would all be appropriate considerations.

59 Parents may still be successful in asserting free exercise challenges in the context of public schools where the school more directly compels conduct prohibited by the beliefs of the child's family. See, for example, Altman v Bedford Central School District, 45 F Supp 2d 368 (S D NY 1999) (finding that school project requiring students to design and make a representation of a Hindu god violated parents' free exercise rights).

$60 \quad 827$ F2d 1058 (6th Cir 1987).

61 Id at 1067 ("The plaintiff parents can either send their children to church schools or private schools, as many of them have done, or teach them at home."). 
C. The Theorists

Allocating educational control between parent and state has become a central focus for political theorists seeking to define the scope of legitimate state authority over individual conduct in a diverse society. Many of these "liberal" political theorists have addressed Yoder directly, treating it as the paradigm case in which a community's pursuit of its distinct conception of the good life is pitted against the state's interest in cultivating certain attributes in its citizens. ${ }^{{ }^{2}}$ Although the theorists often criticize the Court's analysis, particularly of the state interests at stake, they ultimately fall into the same trap as the Court in considering how those state interests are to be achieved. They too focus on the substance of curricular offerings and ignore the importance of peer interactions.

Liberal theorists have identified a host of state interests implicated by educational policies, most of which parallel the interests in fostering self-reliance and political participation identified by the courts. ${ }^{{ }^{3} 3}$ They also focus considerable attention, however, on an interest largely ignored by the courts - the interest in fostering children's ability to act autonomously, to make decisions "for themselves,", determined by their particular values and dispositions. ${ }^{\text {" Despite their }}$

62 See, for example, Martha C. Nussbaum, The Role of Religion, in Women and Human Development: The Capabilities Approach ch 3 (Cambridge 2000); Richard Arneson and Ian Shapiro, Democratic Autonomy and Religious Freedom: A Critique of Wisconsin v. Yoder, in Ian Shapiro, ed, Democracy's Place 137, 139 (Cornell 1996) (arguing that "parents' claims should not displace a democratic state's requirement of compulsory education to an age when critical reason is developed and can be fully deployed"); Amy Gutmann, Civic Education and Social Diversity, 105 Ethics 557, 558 (1995) (examining Yoder as a "test case[ ] of conflict between social diversity and civic education"); Stephen Macedo, Liberal Civic Education and Religious Fundamentalism: The Case of God v. John Rawls?, 105 Ethics 468, 488-89 (1995) (noting that the Amish present a unique situation because they are "sectarians living apart" from the rest of society); William A. Galston, Two Concepts of Liberalism, 105 Ethics 516, 516 (1995) (noting that his essay was inspired by his "long-standing interest in the case of Wisconsin v. Yoder"); Jeff Spinner, The Boundaries of Citizenship: Race, Ethnicity and Nationality in the Liberal State 88-92 (Johns Hopkins 1994); Amy Gutmann, Democratic Education 29 (Princeton 1987) (noting that the Amish parents in Yoder present an extreme example of parents denying their children the "skills necessary for rational deliberation"). Others appear to be addressing the case, without naming it. See, for example, John Rawls, Political Liberalism 199 (Columbia 1996) ("[V]arious religious sects oppose the culture of the modern world and wish to lead their common life apart from its unwanted influences. A problem now arises about their children's education and the requirements the state can impose.").

63 See, for example, Rawls, Political Liberalism at 199 (cited in note 62) (describing as the legitimate aims of education to "prepare [children] to be fully cooperating members of society and enable them to be self-supporting; it should also encourage the political virtues so that they want to honor the fair terms of social cooperation in their relations with the rest of society").

64 What constitutes an autonomous act is not easy to define. As we shall see, the psychological literature on identity formation focuses on subjective perceptions in determining which decisions can be considered a person's "own."

65 Arneson and Shapiro, Democratic Autonomy at 156 (cited in note 62) (describing their position as arguing for "the moral imperative of educating for autonomy"); Gutmann, Democ- 
greater ambitions for state educational influence, however, theorists championing education for autonomy maintain a narrow focus on imparting information as the primary, if not the only, means of exerting educational influence. Joel Feinberg, in his seminal piece "The Child's Right to an Open Future," is perhaps the most explicit in his singleminded attention to substance. Although he calls for the protection of children's "anticipatory autonomy rights" through education, he suggests that the means of ensuring that autonomy is to fill a child with "knowledge and skills that will help him choose whichever sort of life best fits his natural endowment and matured disposition," "a great variety of facts and diversified accounts and evaluations of the myriad human arrangements in the world and in history."

Other theorists focus more specifically on the importance of children's acquiring critical reasoning skills as a precondition for autonomy. In the words of Richard Arneson and Ian Shapiro, "[ $t]$ he autonomous person is ... one who is capable of standing back from her values and engaging in critical reflection about them and altering her values to align them with the results of that critical reflection." In the words of Amy Gutmann, education "makes choice meaningful," by developing the "intellectual skills necessary to evaluate ways of life different from that of [one's] parents." As Gutmann's statement makes plain, these theorists equate the state's facilitation of critical reasoning and self-reflection with skills training: schools teach chil-

ratic Education at 30 (cited in note 62 ) (arguing that " $[\mathrm{t}]$ he same principle that requires a state to grant adults personal and political freedom also commits it to assuring children an education that makes those freedoms both possible and meaningful in the future"). To some, this capacity for autonomy has intrinsic value; for others, the capacity is justified in instrumental terms (autonomous choice facilitates an individual's pursuit of the good). See Arneson and Shapiro, Democratic Autonomy at 167 (listing this instrumental value as one among three justifications for making the capacity for autonomous decisionmaking a central aim of education); Gutmann, Democratic Education at 44 (contending that "a democratic state must aid children in developing the capacity to understand and to evaluate competing conceptions of the good life and the good society"). For still others, possession of the capacity to exercise independent choice is considered a necessary prerequisite to the political participation expected of citizens in our system of democracy. See, for example, Rawls, Political Liberalism at 199-200 (cited in note 62) (suggesting that the state's championing of autonomous decisionmaking, grounded on rational deliberation, should be limited to the context of the political realm). See also Amy Gutmann, Children, Paternalism, and Education: A Liberal Argument, 9 Phil \& Pub Aff 338, 350 (1980) ("A child's right to education is a necessary precondition for the development of capacities ... to employ the political freedoms of democratic citizenship.").

66 Joel Feinberg, The Child's Right to an Open Future, in William Aiken and Hugh LaFollette, eds, Whose Child? Children's Rights, Parental Authority, and State Power 124, 134-35 (Rowman and Littlefield 1980).

67 Id at 139. Compare Macedo, 105 Ethics at 487 n 59 (cited in note 62) (noting that "knowledge of the diversity that constitutes our history and the importance of tolerance are clearly among the core civic aims," and are more central to the civic mission of schools than science classes).

68 Arneson and Shapiro, Democratic Autonomy at 162 (cited in note 62).

69 Gutmann, Democratic Education at 30 (cited in note 62). 
dren how to reason, a skill they can then apply outside of the school context in making choices about how to live their lives.

It is worth noting that the centrality of autonomy as an educational goal is the subject of much debate among liberal theorists. Though the "political liberals," led by John Rawls, eschew the state's championing of the ideals of autonomy or individuality over other comprehensive conceptions of the good, they nevertheless call for the state to protect children's opportunity to exit from the community of their parents if they so choose; ${ }^{71}$ and they, too, rely on the substance of curricular offerings to secure this exit opportunity. In the words of Rawls:

[P]olitical liberalism ... will ask that children's education include such things as knowledge of their constitutional and civic rights so that, for example, they know that liberty of conscience exists in their society and that apostasy is not a legal crime, all this to insure that their continued membership when they come of age is not based simply on ignorance of their basic rights or fear of punishment for offenses that do not exist. ${ }^{1}$

While limiting the state to providing basic information may help prevent the state from intruding upon parental control over the development of their children's "comprehensive doctrine," it will do so at a big cost in effectiveness. Giving children mere information about their right to leave will do little to facilitate their actual capacity to leave. Unless the state is committed to facilitating that capacity, providing information will be little more than a rhetorical gesture.

In fairness to the theorists, I should acknowledge that a few of them have mentioned the value of peer interactions in the educational process. ${ }^{3}$ However, even to the extent that the value of interaction ac-

70 The tension created by the attempt to avoid promoting autonomy outside of the political realm, while preserving children's capacity to exercise it, is evident throughout discussions of political liberalism. See, for example, Macedo, 105 Ethics at 488 (cited in note 62) ("While the state has no business promoting broad ideals like personal autonomy, moreover, to allow Amish parents to withdraw their children from high school could thwart the children's ability to make adequately informed decisions about how to live their lives."). Rawls concedes that, in at least some cases, "requiring children to understand [his proposed] political conception in these ways is in effect, though not in intention, to educate them to a comprehensive liberal conception" which embraces autonomy as an ideal. Rawls, Political Liberalism at 199 (cited in note 62). Even William Galston, who argues that the political liberals do not go far enough in deferring to the educational choices of diverse communities, concludes that the state has an interest in preserving the individual's opportunity for "meaningful exit" and that this interest "brings us back some distance toward policies more typically associated with autonomy concerns." Galston, 105 Ethics at 534 (cited in note 62).

71 Rawls, Political Liberalism at 199 (cited in note 62).

72 Id at xviii.

73 See, for example, Martha Minow, Not Only for Myself: Identity, Politics, and the Law 114-17 (New Press 1997) (noting the ways in which parents with sufficient resources can select 
knowledged in these discussions can be distinguished from the value of exposure to diverse ideas (a substance-focused value achievable through texts as well as personal interactions) that value is not recognized to include the direct role the interactions play in the identity formation process. ${ }^{74}$ Instead, theorists point to two other values: first, the skill-building value provided by the opportunity to practice critical reasoning and political deliberation, ${ }^{75}$ and, second, the toleranceteaching value provided by the exposure to different opinions and their defenses. While the first of these values at least concedes an indirect influence on identity (interaction teaches critical reasoning, critical reasoning is then applied to life choices), the second is built on an assumption that there will be no such effects. Learning toleration suggests a change in attitudes about difference, not an alteration in the differences themselves. ${ }^{76}$

None of these theorists focuses on the value of peer interactions for their direct effect on an individual child's identity development. Overlooking the developmental significance of these interactions is not simply a problem of academic incompleteness. The theorists' incomplete account leads them to adopt policy positions that a better understanding of adolescent development suggests may actually disserve their own principles. In particular, their focus on facts and skills leads even those theorists most eager to facilitate children's autonomy to condone private religious schools, so long as those schools comply

the peers encountered by their children); Gutmann, Democratic Education at 107 (cited in note 62) ("However students have been socialized outside of school, there should be room within school for them to develop the capacity to discuss and defend their political comitments with people who do not share them.").

74 Martha Minow comes the closest to addressing the issue. In Chapter 5 of Not Only for Myself, she acknowledges the link between educational choices and identity formation, and she specifically notes that school choices include choices about peers as well as about curriculum. Minow, Not Only For Myself at 106-33 (cited in note 73). She does not, however, address the relationship between peer interaction and identity formation, and it is clearly not her aim to consider the process through which identity formation occurs.

75 Gutmann, Democratic Education at 106-07 \& n 27 (cited in note 62) (concluding that "[t]he most relevant result" of a course that encouraged students to debate political issues among themselves would be "an increase in the ability of students to reason, collectively and critically, about politics, an ability ... essential to democratic citizenship," and citing a study that suggested that students exposed to extensive classroom discussion "demonstrated both better reasoning capacities and more factual knowledge").

76 Minow, Not Only For Myself at 126 (cited in note 73) (suggesting that "integration across varied divides would not eradicate difference, but instead nurture self-conscious acknowledgement of identities, and the grounds for tolerance itself. For tolerance has no occasion to be tested, or strengthened, in the absence of differences that trigger genuine disagreement."); Gutmann, Democratic Education at 33 (cited in note 62) (suggesting that exposing children to "ways of life different from their parents ... [will lead children to] embrace certain values, such as mutual respect among persons, that make social diversity both possible and desirable"); Gutmann, 105 Ethics at $567 \mathrm{n} 17$ (cited in note 62) (citing empirical support for the conclusion that formal education is correlated with children's development of tolerance, and that both the content taught and the pedagogical methods employed influence the success of attempts to teach tolerance). 
with certain curricular standards. ${ }^{n}$ Without acknowledging the price, ${ }^{78}$ they cede to parents control over precisely those peer interactions that may most influence children's opportunity to develop the capacity for independent choicemaking.

\section{THE DEVELOPMENTAL STAKES}

The courts' and commentators' account of the state's interests in educating adolescents demonstrates a lack of attention to the core tasks of adolescent development, and a lack of understanding of how peer interactions in schools can influence that development. By early adolescence, much of the hard work of cognitive development is behind children. ${ }^{79}$ What lies ahead, as the developmental preoccupation of late adolescence and early adulthood, is identity development. Adolescents are engaged in the process of figuring out who they areparticularly how they are like and unlike the models established for them by their parents - and their relations with peers play a major role in the process. It is this identity formation process, and the path it takes through peer interactions, that is most affected by the changes in policy and court decisions that cede control over educational place-

77 Arneson and Shapiro, Democratic Autonomy at 157 (cited in note 62) (noting that the reversal of Yoder on the grounds they advocate would not require the Amish to send their children to secular schools); Gutmann, Democratic Education at 117 (cited in note 62) (arguing that "[a] better alternative to prohibiting private schools would be to devise a system of primary schooling that accommodates private religious schools on the condition that they, like public schools, teach the common set of democratic values"); Amy Gutmann, Religion and State in the United States: A Defense of Two-Way Protection, in Nancy L. Rosenblum, ed, Religion and Law: Obligations of Citizenship and Demands of Faith (Princeton 2000) (asserting that "[d]emocratic authority over education also has important limits, which permit religious and irreligious parents alike to send their children to private schools, which may teach their religion or irreligion in addition to the state requirements of civic education"); Macedo, 105 Ethics at 486 (cited in note 62) ("I would concede the right to opt out of public schooling, but that right should be understood to be conditioned by a public authority to regulate private schools to insure that civic basics are taught."). This position echoes that of John Stuart Mill, who contended that the role of education was to maximize a child's future choices, that private/parental control of the schools would better serve this end, but that such control must be subject to the supervision of the state in the form of public examinations testing a child's knowledge of "facts and positive science exclusively." John Stuart Mill, On Liberty ch 5, 14 at 99 (Norton 1975).

78 Gutmann does consider whether outlawing private schools could be justified, but her assessment of the risks posed by parents' ability to remove their children from public schools focuses on the potential depletion of resources and academic performance the removal would cause, rather than the diminution of opportunities for unlike peers to interact. See Gutmann, Democratic Education at 116 (cited in note 62). Indeed, Gutmann expressly concedes that allowing private schools will facilitate parents' segretation of their children from peers who do not share their religious beliefs, but does not consider this problematic, so long as the children are taught a "common set of democratic values." Id at 117.

79 Doris R. Entwisle, Schools and the Adolescent, in S. Shirley Feldman and Glen R. Elliott, eds, At the Threshold: The Developing Adolescent 197, 197 (Harvard 1993) (asserting that, by adolescence, the pace of cognitive development has slowed to one-tenth of its elementary school pace). 
ment to parents. An understanding of this development is therefore essential to careful lawmaking in this area.

In this Part, I will explore the developmental process, first by discussing the significance of identity formation to adolescents generally, and second by considering the relative influence of parents and peers on that process. My discussion of adolescent identity formation will highlight the value attributed by many developmentalists to the process of identity exploration, which has been correlated both with more successful functioning and with an individual's greater sense of personal control over her choices. The state's interests in children's development into healthy and productive adults, and in their development into autonomous participants in the democratic process, are implicated by policies affecting children's opportunity to engage in identity exploration.

A consideration of how the state might facilitate identity exploration takes us to our second developmental topic, namely the influence of parents and peers on the identity formation process. My survey of the relevant literature reveals that both parents and peers profoundly affect an adolescent's identity development, but that their influence operates in significantly different ways. Where parents tend to exert the primary influence over the substance of adolescent's choices, particularly about the important issues such as religion that are our focus here, peers play a critical role in the process of identity formation. Peer interactions offer the best opportunity for exploration, and this opportunity is considerably enhanced if the peers with whom the adolescent interacts differ in background and convictions from herself. Even where, as is often the case, the exploration does not alter the adolescent's ultimate choices, it is likely to alter the adolescent's perception of control over the choicemaking.

\section{A. Why Social Science?}

My ultimate task, which I will take up in Part III, is to consider how, if at all, a more sophisticated understanding of child development changes how we should analyze parents' attempts to control their children's education, particularly for religious reasons. Before digging into the developmental literature, I wish to consider the appropriateness of this interdisciplinary inquiry.

Put simply, an understanding of development is important because the law affecting children is grounded on developmental assumptions. ${ }^{80}$ The law frequently treats children differently from adults,

80 In analyzing the law as it applies to children, developmental assumptions come into play in two ways that roughly correlate with discussions of children's legal rights, on the one hand, and children's needs and interests, on the other. In considering the proper scope of children's 
and this difference in treatment is justified by the perception that children's cognition, social skills, moral values, and functional competencies are not fully ${ }^{81}$ developed. ${ }^{82}$ Courts and commentators point to children's immaturity and related dependency to justify placing control of important decisions in the hands of parents and the state, and to justify the allocation of surrogate decisionmaking between parents and the state.

To say that children's incomplete development serves to justify their special treatment under the law is not to say that decisions about how the law should treat children are well grounded in an understanding of how children actually develop. Indeed, much of the law affecting children rests on simple assertions that children are developmentally different, or unsupported assumptions about the nature of those differences. ${ }^{84}$ The value of turning to the developmental literature is

right to exercise decisionmaking control, the courts make express or implied assumptions about children's capacities and rely on assumptions about children's insufficient development to justify curtailing children's rights. See, for example, Bellotti v Baird, 443 US 622, 634-39 (1979) (justifying state imposition of special restrictions on minors' abortion rights that would be unconstitutional if applied to adult women on the basis of minors' lesser capacity for decisionmaking and their dependent relationship on their parents). In this context, the assumptions are about developmental status, and differences in status serve to justify a diminution in rights. In contrast, the developmental assumptions underlying consideration of children's needs and interests, such as the educational interests at issue in our cases, go as much to process as to status. In this context, the ongoing nature of children's developmental process justifies special legal rules aimed at affecting and protecting that process. See, for example, Yoder, 406 US at 221 (noting the importance of the state's educational role in developing children's capacities to support themselves and participate in the political process); Prince v Massachusetts, 321 US 158, 168 (1944) (asserting that the state has an interest in securing "the healthy, well-rounded growth of young people into full maturity as citizens, with all that implies").

81 I note that the concept of "full" or complete development is simplistic. The term "development" is increasingly used to describe the ongoing process of change over the course of a lifetime. See, for example, Paul B. Baltes, Ulman Lindenberger, and Ursula M. Staudinger, Life-Span Theory in Developmental Psychology, in William Damon, ed, 1 Handbook of Child Psychology 1029,1029 (Wiley \& Sons 5th ed 1998) (explaining that a "core assumption of life-span developmental psychology is that development is not completed at aduithood"). The legal concept of development, however, draws a clean line at adulthood.

82 See, for example, Bellotti, 443 US at 634 (explaining that "[w]e have recognized three reasons justifying the conclusion that the constitutional rights of children cannot be equated with those of adults: the peculiar vulnerability of children; their inability to make critical decisions in an informed, mature manner; and the importance of the parental role in child rearing").

83 See, for example, Parham v J.R., 442 US 584, 604 (1979) (concluding that children's interests were best served by refusing to recognize their due process right to an independent hearing prior to a mental health commitment, instead leaving parents with "plenary authority to seek such care for their children, subject to a physician's independent examination and medical judgment").

84 For example, compare id at 603 (asserting, without support, that "[m]ost children, even in adolescence, simply are not able to make sound judgments concerning many decisions, including their need for medical care or treatment"), with Thomas Grisso and Linda Vierling, Minors' Consent to Treatment: A Developmental Perspective, 9 Professional Psych 412, 424 (1978) (concluding, on the basis of a literature review, that "[t]here appear to be no psychological grounds for maintaining the general legal assumption that minors at age 15 and above cannot provide 
therefore the simple value of improving the understanding of children that serves as the basis of their legal treatment.

While simple in its value, the developmental inquiry is far from simple in its application. There are many ways in which this social science literature could be misread or overread, and a brief consideration of the limitations of this literature will help ensure its proper use in our inquiry. In general, objections to relying on social science literature can be roughly divided into two categories: the first focuses on the indeterminate nature of the available information, and the second on the information's context dependence. The first category of objections points to the lack of any direct testing of many of the specific questions the law confronts, the potential methodological weaknesses of studies, the limitations on the conclusions that can be drawn from even the best studies, and the inconsistency of results from one study to the next. The second category of objections focuses on sampling issues, and the role context, and particularly cultural context, plays in shaping how studies are designed, what results are obtained, and how those results are interpreted. ${ }^{\text {\&o }}$ We worry about the first category of objections because they call into question how much we can learn from the professionals about how any child develops, and we worry about the second category of objections because they suggest that whatever we can learn from the literature says at least as much about our culture's expectations and values as about inherent capacities.

Both categories of objections are important, but neither, in my view, counsels against giving the developmental literature careful consideration. While developmentalists surely do not have all the answers, they are asking important, relevant questions, and as incomplete and uncertain as their answers are, they are far better grounded, or more carefully qualified, than lawmakers' guesses. Moreover, to the extent the law is premised on developmental assumptions that remain untested, only a careful consideration of the developmental literature can illuminate these gaps.

competent consent" to treatment).

85 See, for example, Sarah H. Ramsey and Robert F. Kelly, Using Social Science Research in Family Law Analysis and Formation: Problems and Prospects, 3 S Cal Interdiscipl L J 631, 634 (1994) (listing, among other methodological problems with social science research, problems of measurement, assessing causal linkage, and skewed interpretation by biased researchers).

86 See, for example, Sally L. Archer, A Feminist's Approach to Identity Research, in Gerald R. Adams, Thomas P. Gullotta, and Raymond Montemayor, eds, Adolescent Identity Formation 26 (Sage 1992) (citing numerous examples where the most influential developmentalists relied heavily, if not exclusively, on studies in which the subjects were white boys from academically and professionally successful families); Martha L. Fineman and Anne Opie, The Uses of Social Science Data in Legal Policymaking: Custody Determinations at Divorce, 1987 Wis L Rev 107, 109-10 (contending that social science research on topics related to custody focuses disproportionally on fatherhood which has the effect of devaluing mothers' contributions). 
As for the contextual concerns, while developmentalists' conclusions will inevitably reflect the culture in which their studies are conducted, these conclusions will at least tell us something about developmental possibilities. As important, they can tell us a great deal about developmental influences. How much we as a society choose to value various developmental ends over other goals will ultimately be a moral and political choice, but ascertaining how to achieve the ends we value will require an understanding of these developmental influences. ${ }^{\text {"T }}$

The objections, of course, are not so much to the studies themselves as to their misuse and manipulation in the hands of their interpreters. ${ }^{\$}$ In light of the seriousness of this risk, it is worth clarifying the nature of my task. My intention is to stimulate interdisciplinary discussion, not to provide the final word on children's development. I consider my attempt to link law to developmental studies part of an ongoing process of interdisciplinary work that should run in both directions. Just as the legal inquiry should be informed by the current state of developmental knowledge, so should the developmental inquiry, going forward, take better heed of the legal issues to be resolved, and the legal context in which development occurs. A better discussion between the disciplines should, over time, produce better answers to both methodological concerns, and the larger issues driving the inquiry.

While the objections I have discussed do not counsel against pursuing the developmental inquiry, they should guard against any suggestion that developmental psychology provides "easy answers." The value of the inquiry is not that it can simplify the analysis but rather that it can facilitate a more intelligent consideration of complexities. The law's special treatment of children should be informed by as sub-

87 In looking to the literature for this understanding, we must, of course, take care in distinguishing correlation from causation. See Ramsey and Kelly, 3 S Cal Interdiscipl L J at 648 (cited in note 85) (discussing the "difficulties involved in establishing causal relationships in family social science").

88 See, for example, William Gardner, David Scherer, and Maya Tester, Asserting Scientific Authority, Cognitive Development and Adolescent Legal Rights, 44 Am Psych 895 (criticizing the misuse of developmental theory and data in amicus briefs to argue for the elimination of restrictions on a minor's right to an abortion).

89 Understanding children's development can lead to more sophisticated lawmaking on several levels: most obviously, to the extent legal rules are grounded exclusively on developmental assumptions, a better understanding of development will produce better justified rules and, where assumptions are shown to be incorrect, better rules. The developmental inquiry can have other beneficial analytic effects: where developmental effects point in one direction, but the law in another, the developmental inquiry may help to illuminate what other considerations are at stake, and what relative weight is being afforded to these various considerations. Moreover, the precision required to frame a useful developmental inquiry can help clarify the nature and scope of the various interests at stake, even if the inquiry does not produce definitive social scientific conclusions. 
tle an understanding as possible about what is and is not known about the relevant stakes for children of the legal regime. The legislatures and the courts then have the hard task of deciding how that developmental understanding should affect the law.

I have argued that the courts' analysis in these cases reflects an attempt to weigh the relative costs and benefits to children of allowing the state to enforce its educational requirements on the one hand, and deferring to particular parents' religiously motivated judgments on the other. Similarly, state policies allocating educational control between parents and the state reflect policymakers' assessments of the relevant benefits of parental or state control for children. This weighing is, at its core, a developmental inquiry -it asks who can and should have what influence over how children grow up, and by what means that influence should be exercised. In Part II.B, I will bring the developmental inquiry to the fore, focusing particularly on adolescence, where the balancing problem becomes most complex. I will pay special attention to religious identity development because this is the area in which parents' interest in control is generally greatest, and, relatedly, where that interest has the most constitutional protection. It is in this context that the state's competing interest in associational control is most sharply tested, for only the strongest state interests can justify interference with parental control.

\section{B. The Developing Adolescent}

The major developmental task of adolescence in western cultures ${ }^{\text {sin }}$ is identity formation, and this task is accomplished in large part through peer interactions. Who those peers are, and the nature of those interactions, will inevitably have a considerable effect on who adolescents become. In light of the evident importance of the choice of peer associations to children's development, it is striking how little consideration is given, by courts, policymakers, and political theorists alike, to the associational implications of their decisions and policies.

In this Section, I will begin by describing developmentalists' understanding of the process of identity formation, and how it can vary in its path and its endpoints. After discussing identity formation in general terms, I will consider more particularly adolescents' development of a religious identity, noting that this development can be understood to include both the development of a sense of group affiliation and the development of a sense of personal religious values and

90 While there is considerable variety in the groups represented in the litigation pressing for parental control over educational choices, they all appear to recognize a developmental transition period between childhood and adulthood that spans a considerable portion of the teenage years. 
commitments. I will then consider the influences on the different aspects of identity development, focusing on the comparative influence of parents and peers. While both parents and peers exert significant influence over the identity formation process, interactions with parents are central for much of childhood, whereas peer interactions become increasingly influential in middle and late adolescence. The difference in the timing of these influences corresponds to some differences in the nature of the influence. While parents exert the primary influence over adolescents' choice of long-term goals and values and their sense of group affiliation, peers play an important role in influencing how adolescents engage in and perceive the choicemaking process. How this choicemaking process is experienced, I will argue, may affect the extent to which choices made can be characterized as autonomous.

\section{Identity formation.}

Sorting out our identities is a lifelong project." Infants discover that they are distinct from their caregivers and that they can exercise some control over their bodies and their environment. ${ }^{92}$ Young children discover what they are good at, what they like to do, and with whom they like to play. ${ }^{93}$ But it is in adolescence that the concept of self-the integrated composite of personality, tastes, values, skills, and behaviors-is most thoroughly and self-consciously developed. ${ }^{\text {s4 }}$ This identity formation concentrates in adolescence in part because it rests on certain cognitive advancements: by mid-adolescence, most individuals have developed the capacity to engage in abstract thinking, which allows for a consideration of overarching principles and alterna-

91 Jane Kroger, Identity in Adolescence: The Balance Between Self and Other 18 (Routledge $2 \mathrm{~d}$ ed 1996) (describing the Eriksonian view that identity "evolves through earlier stages of development and continues to be reshaped throughout the life-cycle").

92 See Eleanor E. Maccoby, Social Development: Psychological Growth and the ParentChild Relationship 251 (Harcourt 1980) (noting that, while the time of discovery cannot be identified with any precision, it appears that children begin to pull together sense impressions of their own bodies, movements, and cries in a single perception of bodily self early in infancy).

93 See William Damon and Daniel Hart, Self-Understanding in Childhood and Adolescence 59 (Cambridge 1988) (describing early childhood identity descriptions as descriptions of categories such as "group memberships, typical activities, and physical characteristics").

94 See Harold D. Grotevant, Assigned and Chosen Identity Components: A Process and Perspective on Their Integration, in Adams, Gullotta, and Montemayor, eds, Adolescent Identity Formation at 73 (cited in note 86) (describing identity development as a "key developmental task for adolescents in Western societies"); Kroger, Identity in Adolescence at 21, 46 (cited in note 91) (noting the importance of adolescence for identity development).

95 Carol Markstrom-Adams, A Consideration of Intervening Factors in Adolescent Identity Formation, in Adams, Gullotta, and Montemayor, eds, Adolescent Identity Formation at 179-80 (cited in note 86) (noting that both Erikson and Piaget contended that the ability to engage in "formal operational" thinking was necessary to engage in the identity formation process, and that some, but not all, studies considering this question have supported this contention). 
tive hypothetical worlds, ${ }^{\%}$ and the capacity to coordinate multiple viewpoints, or "perspectives," which facilitates reflection and selfawareness. The identity formation process is also prompted, at least in western cultures, ${ }^{98}$ by what lies ahead: imminent independence from parents, and the resulting need to make important decisions about work, friendships, lifestyle, and family, focus the adolescent's attention on her identity. ${ }^{\text {s9 }}$ Of course, identity formation continues beyond adolescence (indeed, the very decisions in question will as much shape as be shaped by an individual's concept of identity). But in no other period is identity formation as intense or as central.

Erik Erikson was the primary pioneer in the study of identity development, and his theory of identity formation, first articulated four decades ago, still serves as the starting point for much contemporary analysis of the subject. Erikson suggested that a major shift occurs in adolescence, when the earlier childhood process of "identification" (the assumption of the values and roles associated with admired others) is replaced by the process of identity formation. During this latter

96 Id at 180 (noting that "[a]n inability to examine several possible identity alternatives" circumscribes the identity formation process).

97 Harold D. Grotevant and Catherine R. Cooper, Individuation in Family Relationships: $A$ Perspective on Individual Differences in the Development of Identity and Role-Taking Skill in Adolescence, 29 Hum Dev 82, 86-87 (1986) (citing Robert Selman, and other developmentalists, for their work documenting the development of socio-cognitive, perspective-taking skills through adolescence). The following passage by Erikson captures the sophistication of social cognition demanded by the identity formation process:

[I]dentity formation employs a process of simultaneous reflection and observation, a process taking place on all levels of mental functioning, by which the individual judges himself in the light of what he perceives to be the way in which others judge him in comparison to themselves and to a typology significant to them; while he judges their way of judging him in the light of how he perceives himself in comparison to them and to types that have become relevant to him.

Erik H. Erikson, Identity: Youth and Crisis 22-23 (Norton 1968). See also Ray R. Buss and Robert D. Enright, Helping Adolescents Improve Their Ego-Identity, in John C. Coleman, ed, Working with Troubled Adolescents 153 (Academic 1987) (contending that "social perspectivetaking.... is crucial in identity formation").

98 Note that the very concept of adolescence, let alone the developmental significance of this stage, is culture-specific. In many cultures, individuals are expected to take on adult-like roles when they reach puberty, and whatever developmental work is required to prepare them for these roles will occur earlier in childhood. See Mary Ellen Goodman, The Culture of Childhood: Child's-Eye Views of Society and Culture 3 (Teacher's College 1970) (noting that there is considerable variation among cultures in behavior of adolescents, and attributing that to differences "in culturally patterned expectations, in training, and in social controls"). While there is considerable variation among the cultural groups represented in our cases, adolescence in all these cultures is a period during which individuals prepare for, but do not for the most part yet undertake, adult responsibilities. This similarity across cultures may be, in part, because they are all governed by the same legal structure, which sets the age of adulthood at eighteen for most purposes.

99 Note that the developmental focus on identity need not be equated with a focus on individuality. In cultures oriented toward a group rather than individual identity, an adolescent's identity work may be heavily focused on discovering her fit within the group. 
phase, the adolescent selects among these earlier identifications, embracing some and rejecting others, and in the process develops and reveals her ${ }^{100}$ own integrated set of values and tastes. Erikson suggested that this process of identity formation - the development of a "subjective sense of an invigorating sameness and continuity" to healthy development. In his view, facing, and resolving, the "identity crisis" enables individuals to make important life choices that will serve their unique needs and talents, give them a kind of stability and security that equips them to remain faithful to their commitments and handle life's vicissitudes, and prepares them to enter relationships of intimacy. ${ }^{1 / 2}$ Put simply, Erikson contended that the way the identity formation process unfolds in adolescence and young adulthood has a dramatic effect on the entire life course of individuals.

Erikson perceived the identity formation process as a considered choicemaking process, and his use of the term "crisis" attempted to capture the necessity of confronting and making these choices. Building upon Erikson's theories, James Marcia suggested that the identity formation process reflects development along two different axes: the experience of crisis (doubt and indecision accompanied by an awareness of multiple competing possibilities) and the undertaking of commitments (resolution of these doubts and selection among the possibilities). These axes, considered together, allowed him to categorize all individuals into four identity statuses. Individuals who have gone through a crisis period and then undertaken commitments were labeled identity achieved, or achievements. Individuals who have confronted the crisis but not yet undertaken commitments were labeled moratoriums. Individuals who have undertaken commitments without

100 Those familiar with Erikson's work may take note of my choice of "she" as the generic pronoun. Erikson's empirical work focused heavily on males, and when he turned his attention to identity formation in females, he developed a theory of the "inner space" that has been soundly criticized on the level of both method and theory. See Serena J. Patterson, Ingrid Sochting, and James E. Marcia, The Inner Space and Beyond: Women and Identity, in Adams, Gullotta, and Montemayor, eds, Adolescent Identity Formation at 9-22 (cited in note 86) (describing Erikson's "Inner Space" theory and subsequent studies of women's identity development). I choose the pronoun advisedly, on the view that Erikson's work that focused on males is now thought to have broad application to adolescents of both sexes in western cultures. Compare David R. Matteson, Exploration and Commitment: Sex Differences and Methodological Problems in the Use of Identity Status Categories, $6 \mathrm{~J}$ Youth \& Adolescence 353, 354 (1972) (criticizing poor design of studies ostensibly aimed at capturing differences between men and women's identity formation process).

101 Erikson, Identity: Youth and Crisis at 19 (cited in note 97) (emphasis omitted).

102 In Erikson's view, where the identity formation process was most successful, individuals would enter adulthood with a "sense of psychosocial well-being ... a feeling of being at home in one's body, a sense of 'knowing where one is going, and an inner assuredness of anticipated recognition from those who count." Id at 165. See also Kroger, Identity in Adolescence at 13-46 (cited in note 91 ) (setting out the link between identity formation and subsequent preparedness for intimacy, in Erikson's stage scheme of crises and resolutions). 
ever experiencing the crisis period were labeled foreclosures. Individuals who have neither experienced crisis nor undertaken commitments were labeled diffusions. ${ }^{103}$ Marcia contended, and numerous subsequent studies have confirmed, that the number of achievements increases with age, as more individuals pass through the crisis and commitment processes. ${ }^{104}$

Both Erikson and Marcia concluded that there were more and less healthy ways of developing an identity. In Erikson's terms, the most healthy adults are those who have confronted and resolved the identity crisis. In Marcia's terms, the healthiest adults are identity achieved. $^{105}$ Like Erikson, Marcia placed particular emphasis on the value of the crisis experience, suggesting that through this experience individuals acquire an understanding of self that equips them to make decisions driven by genuine personal preference rather than externally imposed obligations and expectations. In contrast, individuals who resolve their identity issues without questioning and experimentation are likely to be inflexible, conventional, and authoritarian adults. ${ }^{106}$ Marcia perceived the identity work of moratoriums as incomplete, ${ }^{107}$ but expected them eventually to advance to the status of achievements, whereas he perceived foreclosures as potentially locked into a deficient identity resolution that stifled their ability to engage in autonomous action. "Although the term "crisis" has gradually been

103 James E. Marcia, Development and Validation of Ego-Identity Status, 3 J Personality \& Soc Psych 551, 557-58 (1966) (discussing research profiling the four identity statuses).

104 See id at 551-52; Kroger, Identity in Adolescence at 39 (cited in note 91) (citing longitudinal studies showing a progression from non-crisis statuses of foreclosure and diffusion to the mid- and post-crisis statuses of moratorium and achievement); Wim Meeus and Maja Dekovic, Identity Development, Parental and Peer Support in Adolescence: Results of a National Dutch Survey, 30 Adolescence 931, 936 (1995) (citing studies showing "a consistent growth of commitment and exploration as a function of age").

105 See Kroger, Identity in Adolescence at 35-36 (cited in note 91) (summarizing Marcia's findings that achievements showed "flexible strength" and openness); Alan S. Waterman, Identity as an Aspect of Optimal Psychological Functioning, in Adams, Gullotta, and Montemayor, eds, Adolescent Identity Formation at 56 (cited in note 86) (noting that for identity statuses other than identity achieved there were both healthy and pathological aspects, and that even some subset of those with achieved status completed the process prematurely); Michael D. Berzonsky, $A$ Process Perspective on Identity and Stress Management, in Adams, Gullotta, and Montemayor, eds, Adolescent Identity Formation at 194 (cited in note 86) (arguing that achievements and moratoriums are more prepared to adapt to life's vicissitudes because they, unlike foreclosures or diffusions, engage in an information-oriented process of decisionmaking).

106 See Kroger, Identity in Adolescence at 37 (cited in note 91) (summarizing Marcia's findings that foreclosures tended to be rigid, defensive, approval-seeking, and authoritarian).

107 Compare id at 36 (summarizing Marcia's findings suggesting that moratoriums were more anxious than either achievements or foreclosures).

108 Wim Meeus, Toward a Psychosocial Analysis of Adolescent Identity: An Evaluation of the Epigenetic Theory (Erikson) and the Identity Status Model (Marcia), in Klaus Hurrelmann and Stephen F. Hamilton, eds, Social Problems and Social Contexts in Adolescence: Perspectives across Boundaries 83, 94 (Aldine de Gruyter 1996) (describing the "foreclosers" as having mediocre social skills, little cognitive flexibility, and low self-esteem, which comports with Marcia's 
replaced in the literature by the term "exploration" the developmental normality and appropriateness of the experienceErikson's and Marcia's theories are still extremely influential."

Many subsequent studies have supported the correlations between identity exploration and successful adult functioning, and between identity exploration and increased perception of personal control over choices." Others, however, have emphasized that the value of the exploration process is largely context dependent: How this opportunity to explore affects a child, they argue, will surely be affected by whether that child grows up in, and is expected to remain within, a culture that affords individuals the opportunity to make choices. ${ }^{12}$ The

views).

109 See, for example, Grotevant and Cooper, 29 Hum Dev at 86 (cited in note 97) (suggesting that exploration more accurately captures the typical identity formation experience because "many adolescents do not experience this period as a crisis"); Matteson, $6 \mathrm{~J}$ Youth \& Adolescence at $354 \mathrm{n} 3$ (cited in note 100) ("The word 'crisis,' used by Marcia and Erikson, unnecessarily evokes the storm-and-stress view of adolescence, focusing on rebellion against the parents. I think it is more descriptive to refer to this variable as 'exploration."'); Meeus and Dekovic, 30 Adolescence at 932 (cited in note 104) (following "convention" to replace crisis with exploration).

110 See Berzonsky, A Process Perspective on Identity and Stress Management at 193 (cited in note 105) (stating that, while not without its critics, Marcia's identity status paradigm has "dominated the field of identity research" for two decades).

111 See Meeus and Dekovic, 30 Adolescence at 932 (cited in note 104) (summarizing literature associating identity achievement and moratorium with positive characteristics, including high levels of self-esteem, autonomy, and reasoning in terms of moral values, and associating foreclosure and identity diffusion with low levels of those characteristics). Compare Waterman, Identity as an Aspect of Optimal Psychological Functioning at 62-65 (cited in note 105) (reporting study results suggesting that, overall, achievements function at the highest level, but that foreclosures also show high self-esteem, clear goal setting, and low levels of anxiety and reporting findings in some, but not all, studies that foreclosures, as well as diffusions, were less likely to perceive themselves as personally responsible for their actions); Berzonsky, A Process Perspective on Identity and Stress Management at 197 (cited in note 105) (contending that foreclosures possess rigid belief systems, are intolerant of ambiguity, resist dissonant information, and have difficulty evaluating or integrating information from multiple perspectives).

112 Compare Harold D. Grotevant and Catherine R. Cooper, The Role of Family Experience in Career Exploration: A Life-Span Perspective, in Paul B. Baltes, David L. Featherman, and Richard M. Lerner, eds, 8 Life-Span Development and Behavior 231, 242 (Erlbaum 1988) (noting that the value of the identity exploration process depends upon cultural norms and that the equation of family health with adolescent exploration "is most prevalent in societies in which high value is placed on individuals' opportunities to have control over choices that affect their lives"); Grotevant and Cooper, 29 Hum Dev at 86 (cited in note 97) (noting the importance of exploration to identity formation when adolescents "have many options from which they must choose"); Markstrom-Adams, A Consideration of Intervening Factors in Adolescent Identity Formation at 174 (cited in note 95) (reporting studies showing correlation of family, ethnicity, race, and religiousity with differing degrees of exploration); Berzonsky, A Process Perspective on Identity and Stress Management at 194 (cited in note 105) (arguing that the adaptive value of various "socio-cognitive processing styles" cannot be evaluated without considering the cultural context in which the processing styles are manifested); Harold D. Grotevant, Adolescent Development in Family Contexts, in William Damon, ed, 3 Handbook of Child Psychology 1097, 1120 (Wiley \& Sons 1998) (suggesting that the equation of autonomy and emancipation from parents with maturity reflects a cultural bias in developmental psychology); Kroger, Identity in Adolescence at 31, 
more narrowly circumscribed those choices, the more potentially meaningless, even destructive, a process of exploration might be. Of course, the extent to which it is appropriate for the state to influence a child's cultural context (by, for example, increasing the child's opportunity to exercise choice) lies at the heart of any consideration of how to allocate educational control between parent and state.

Deciding what value to place on giving an adolescent an opportunity to engage in extensive identity exploration requires us to address several interrelated empirical and normative questions: To what extent will the process of exploration lead individuals to make a broader range of choices, even if they have grown up in communities where such choices are discouraged? To what extent will the process of exploration change how children see themselves and how they function in such communities, should they decide to stay? How highly should we value a child's identification with the religious beliefs and practices of her parents? And finally, how highly should we value the exploration process itself and the choices that grow out of such exploration? In this Part, I focus on the empirics; in the next, I will take up the normative questions.

Of particular interest for our inquiry is how children develop a religious identity and how that particular aspect of identity formation interrelates with identity formation as a whole. After briefly considering what is encompassed within the concept of a religious identity, I will turn to an examination of two important influences over the progress of identity development-namely parents and peers.

\section{Religious identity formation.}

The development of a sense of religious identity is an important piece of the adolescent's larger identity formation process. ${ }^{1.3}$ Going as it does to the core of one's beliefs, values, practices, and affiliations, sorting out one's own religious identity from that of one's parents is as important as any other sorting that occurs in the identity formation process. This process may be especially important because it is in the area of religion that parents frequently care the most about reproducing their identities in their children. ${ }^{14}$ If the language of "crisis" is ever

33 (cited in note 91) (discussing Erikson's critics, generally, and the potential cultural limitations of his identity crisis theory).

113 Elizabeth Weiss Ozorak, Social and Cognitive Influences on the Development of Religious Beliefs and Commitment in Adolescence, $28 \mathrm{~J}$ for the Scientific Study of Relig 448, 448 (1989) ("For almost a century, psychologists have focused on adolescence as a particularly sensitive and important time in the development of religious faith or disengagement."); Raymond $\mathrm{H}$. Potvin and Che-Fu Lee, Adolescent Religion: A Developmental Approach, 43 Sociological Analysis 131,131 (1982) (describing adolescence as a "critical stage" in the development of religious commitment).

114 The same generally cannot be said of choices of occupations, hobbies, non-religious as- 
appropriate, it may be here, where the prospect of a child's embracing a religious identity that diverges from that of her parents is likely to be considered especially significant to parent and child alike.

While the identity choices made in this area may be of particular importance, the process of forming a religious identity looks much like the identity formation process in other domains, and the developmentalist is interested in answering the same questions about her subjects: What, if any, commitments have the adolescents made? Through what process did they make those commitments? What correlations can we draw between the answers to these questions and indicators of well being? Numerous studies of adults suggest that possessing religious convictions and affiliations correlates with positive health and mental health outcomes, including a greater ability to cope with adversity, a lower incidence of anxiety and mental illness, and higher self-reported levels of happiness and self-esteem. ${ }^{115}$ As in other areas of identity formation, however, many developmentalists have concluded that the process leading to commitment matters more than the ultimate commitments made. ${ }^{116}$

An adolescent may embrace religious beliefs with or without first passing through a period of critical exploration. People can be "foreclosed" in their religious commitments, just as in other areas of commitment. ${ }^{17}$ In this context, as in others, psychologists have found indications that those who embrace religion out of an unreflective sense

sociates, or even, in most cases, political affiliations. While parents may hope their children will follow in their footsteps in any of these areas, they are unlikely to care as much about reproducing these aspects of themselves as they do about the transmission of religious beliefs, nor are they likely to be motivated by a sense of religious obligation in their attempts to secure an identity match in these other areas. Of course, sometimes religious choices are directly connected with professional or associational choices, in which case these other choices may take on the same significance as the religious choices themselves.

115 See Christopher Ellison and Jeffrey Levin, The Religion-Health Connection: Evidence, Theory, and Future Directions, 25 Health Educ \& Behav 700,701 (1998) (concluding, on the basis of a literature review, that religiosity is generally associated with positive health and mental health outcomes). The psychological literature is, of course, far from one-sided on the question. Foremost among religion's skeptics was Freud, who perceived religion as an unhealthy product of seli-deceit. Sigmund Freud, Civilization and Its Discontents 23 (Hogarth 1930) ("[Religion] is so patently infantile, so incongruous with reality, that to one whose attitude to humanity is friendly it is painful to think that the great majority of mortals will never be able to rise above this view of life."). See also Eli S. Chesen, Religion May be Hazardous to Your Health (Wyden 1972) (arguing that religion is best viewed as a kind of commodity capable of harming the consumer if not used carefully).

116 See, for example, Allen E. Bergin, Values and Religious Issues in Psychotherapy and Mental Health, 46 Am Psychologist 394, 399-401 (1991) (noting that healthy religiousness is generally associated with internalized beliefs while unhealthy religiousness generally stems from a desire for security or status).

117 See Mitchell S. Parker, Identity and the Development of Religious Thinking, in Alan S. Waterman, ed, Identity in Adolescence: Processes and Contents 43, 47 (Jossey-Bass 1985) (reporting results of study suggesting that adolescents' religious identities reflect the same distribution over Marcia's identity statuses as other domains of identity development). 
of obligation, to achieve approval, or to avoid feelings of guilt manifest more negative mental health outcomes than do those who experience the embrace of those beliefs as a volitional, self-determined act which assimilates the beliefs into an integrated sense of self. ${ }^{118}$ Regardless of how much stock we want to place in such well-being indicators (I suggest in the final section that such indicators should not serve as the basis for educational policy), we might nevertheless have an interest in fostering the self-directed choicemaking on religious matters that psychologists believe underlies these perceived differences in outcome.

In addition to this belief-focused aspect of religious identity, there is also an affiliation-focused aspect that can best be viewed as a form of ethnic identity. ${ }^{119}$ The strength of this affiliation-based identity will vary considerably among religions, but it is worth noting, albeit somewhat tautologically, that this group identification is likely to be particularly strong in religious groups who hold themselves apart from the rest of society.

Appreciating the distinction between the belief-based conception of religious identity and the affiliation-based conception is important, because the developmental course of these two aspects of identity formation does not appear to be identical. Belief-based religious identity formation largely awaits adolescence, ${ }^{120}$ and for many continues well beyond adolescence. ${ }^{121}$ As with other aspects of identity formation that involve important values, ${ }^{122}$ this is in part because religious belief formation requires the late-developing ability to think abstractly, and in part because it is in adolescence that important life choices begin to

118 See, for example, Richard M. Ryan, Scott Rigby, and Kristi King, Two Types of Religious Internalization and Their Relations to Religious Orientations and Mental Health, $65 \mathrm{~J}$ Personality \& Soc Psych 586, 587, 594 (1993) (noting that those whose religious beliefs and practices are perceived as "personally chosen and valued" test high on indicators of well-being, whereas those whose beliefs and practices are undertaken out of a sense of obligation test lower). Compare Carol Markstrom-Adams and Melanie Smith, Identity Formation and Religious Orientation among High School Students from the United States and Canada, $19 \mathrm{~J}$ Adolescence 247, 258 (1996) (noting a high correlation between "extrinsic" religious focus-defined as religiosity motivated by self-interest rather than principled conviction-and identity diffusion, described as the "least healthy of the identity statuses").

119 See Jean S. Phinney and Doreen A. Rosenthal, Ethnic Identity in Adolescence: Process, Context, and Outcome, in Adams, Gullotta, and Montemayor, eds, Adolescent Identity Formation at 147 (cited in note 86) (defining ethnic identity as the "sense of belonging to an ethnic group").

120 David Elkind, The Development of Religious Understanding in Children and Adolescents, in Merton P.Strommen, ed, Research on Religious Development 655-83 (Hawthorne 1971) (describing five stages in a child's religious development culminating in mid-adolescence).

121 James Fowler, who has written extensively about the "stages of faith," describes this developmental process continuing over the lifespan. See James W. Fowler, Stages of Faith:The Psychology of Human Development and the Quest for Meaning (Harper Collins 1981).

122 See Part II.B.1. 
loom large. ${ }^{123}$ In contrast, there is evidence to suggest that affiliationbased identity formation starts much earlier in childhood. ${ }^{124}$ This affiliation-based spiritual identity may be fairly firmly established by mid-adolescence, when many embrace their religious affiliation through some form of ceremony, such as a confirmation ceremony or a bas mitzvah. Clearly a child's early sense of affiliation will have some effect on her subsequent development of a belief-based identity, and the development of her belief-based identity will affect her sense of affiliations. To explore the nature of these effects I next consider the connection between association and identity.

\section{The influence of others on identity formation.}

a) The role of parents. Children's earliest conceptions of themselves are heavily entangled with their conceptions of their primary caretakers, most commonly their parents. Early perceptions of self are dominated by parental influences not simply because of the disproportionate amount of time spent together, but also because of the particular nature of the relationship between parent and child. The child begins life abjectly dependent on her parents to meet her most basic physical and emotional needs, and the parents meet their responsibilities by asserting considerable authority over the child. Childhood perceptions of self reflect a heavy identification with parents' beliefs, val-

123 Carol A. Markstrom, Religious Involvement and Adolescent Psychosocial Development, $22 \mathrm{~J}$ Adolescence 205 (1999) (suggesting that the acquisition of the ability to think abstractly, the desire to confront important questions and their overall engagement in the process of identity formation incline adolescents to address issues of religion and spirituality); David Elkind, The Child and Society: Essays in Applied Child Development 277-78 (Oxford 1979) (suggesting that the "search for comprehension" inspired by the development of abstract reasoning skills leads adolescents to turn to religion for answers); Everett L. Worthington, Jr., Religious Faith Across the Life Span: Implications for Counseling and Research, 17 Couns Psych 555, 560 (1989) (noting that their newfound ability to manipulate abstract concepts leads adolescents to engage in abstract thought about religion and, in many cases, to embrace a formal religion).

124 A. Khalique, M.K. Jabbi, and L. Chatterjee, Development of Religious Identity and Ethnocentrism in Indian Children: A Pilot Study, 29 Psychological Studies 18 (1984) (citing numerous studies suggesting that ethnic identities develop as early as five years of age). While the issue of ethnic identity development has been studied most thoroughly in the related, but distinct, context of race, see, for example, Jenny Laishley, Skin Colour Awareness and Preference in London Nursery-School Children, 13 Race 47 (1971) (discussing several studies of race awareness and attitudes among children), the question of group identity development along religious lines has received some separate attention, see, for example, M.K. Jabbi, Development of Religious Identity and Prejudice in Sikh Children, 12 Social Change 20, 20 (Dec 1982) (finding that awareness of group religious identification among Sikh children begins as early as four or five years of age, and is well established by eight or nine years of age). There is some evidence to suggest that awareness of group identity develops earliest among children who are members of minority groups. See H. Rahman Khan, A Study of the Development of Religious Prejudice in Children, in Sheo Nath Singh and H. Rahman Khan, eds, Prejudice in Indian Society 128 (Rupa Psychological Centre 1979). 
ues and tastes, ${ }^{125}$ and a conception of morality driven by what will inspire parental approval and disapproval. ${ }^{126}$

This conception of self works well so long as children remain in a condition of dependence, but it must be altered, at least to some degree, before an individual can leave her parents' household and assume adult responsibilities. Psychologists describe this process of separating one's identity from that of one's parents as "individuation." It is important to emphasize that individuation does not require a child to reject her parents or their values. Indeed, a close parent-child relationship has been found to facilitate, rather than impede, the individuation process. ${ }^{127}$ Through individuation, the adolescent discovers herself as a person distinct from her parents, but, in so doing, she may very well embrace the choices of her parents.

In considering the nature of the individuation process, it is, again, impossible to divorce development from context. While some of the drive to form an identity separate from one's parents is thought to come from cognitive and biological changes, this process of individuation is also inspired by societal expectations. ${ }^{128}$ In all the cultural contexts considered in our cases, children are expected to remain dependent upon, and under the ultimate authority of, their parents until the late teenage years, after which they are expected to function independent of parental control. ${ }^{129}$ Even in communities where children are expected to grow up to assume roles and values identical to those

125 Indeed, the youngest children are seen frequently to confuse their own thoughts and viewpoints with those of their parents. See William Damon, The Social World of the Child 179-80 (Jossey-Bass 1977) (describing children's confusion of their own wishes with those of their parents and distortion of their parents' wishes to make them conform with their own); Maccoby, Social Development at 262 (cited in note 92) (describing the two-year old's inability to distinguish her own sensory experience and dreams from the experiences of her mother).

126 See Lawrence Kohlberg, The Development of Children's Orientations Toward a Moral Order: Sequence in the Development of Moral Thought, in William Damon, ed, Social and Personality Development: Essays on the Growth of the Child 388, 390 (Norton 1983) (noting that young children's perception of morality is associated with the avoidance of punishment and disapproval).

127 Grotevant and Cooper, 29 Hum Dev at 96 (cited in note 97) (finding support in the individuation literature for the thesis that "the co-occurrence of individuality and connectedness in family relations contributes to the adolescent's ability to explore identity-related choices and coordinate multiple perspectives").

128 B. Bradford Brown, Peer Groups and Peer Cultures, in Feldman and Elliott, eds, At the Threshold 171, 180-81 (cited in note 79) (noting the role of puberty, socio-cognitive development, and the change in social structures accompanying adolescence in initiating the drive to separate from parents).

129 Indeed, the very legal arguments asserted are premised on a special relationship between parent and child that is extinguished at or around the legal age of majority. This is surely in part due to the fact that the law establishes such a minority-majority line, but there is no reason to think parents could not or would not assert a free exercise challenge to the enforcement of that age limit to their authority, if they believed that they were ordained by a divinity to continue to control the upbringing of their children until twenty-five. 
of their parents, children must go through a process of internalization, of assuming values as their own, that will make such role fulfillment possible.

To assist with this developmental shift, adolescents turn from their parents to their peers. This is not to say that parents lose all influence over their children's identity choices. Far from it. Many studies suggest that parents typically exercise more influence than peers over many of their adolescent children's most important long-term decisions, ${ }^{131}$ including religious choices, ${ }^{132}$ particularly where the adolescent perceives the parent-child relationship as close and supportive. ${ }^{133}$ The intensity of the parents' religious practice ${ }^{134}$ and the strength of the

130 See Meeus and Dekovic, 30 Adolescence at 932-33 (cited in note 104) (describing Blos's theory of the "second separation-individuation process," during which the adolescent becomes independent of her parents). Note that the internalization process need not produce exploration. See Ryan, Rigby, and King, $65 \mathrm{~J}$ Personality \& Soc Psych at 586 (cited in note 118) (breaking the religious internalization process into two types-identification and introjection-which roughly track Marcia's categories of achievement and foreclosure, respectively).

131 Brown, Peer Groups and Peer Cultures at 169-72 (cited in note 128) (noting that adolescents look to their parents for guidance in making important long-term decisions); Frank A. Fasick, Parents, Peers, Youth Culture and Autonomy in Adolescence, 19 Adolescence 143, 148 (1984) (noting primary role of parents in instilling values, and reinforcing effect of peer interactions); Willard W. Hartup, Peer Relations, in E. Mavis Hetherington, ed, 4 Handbook of Child Psychology 103 (John Wiley \& Sons 1983) (suggesting that adolescents tend to agree with parents on matters of basic moral principle, future educational and career aspirations, and goals); Don E. Hamachek, Development and Dynamics of the Self, in James F. Adams, ed, Understanding Adolescence: Current Developments in Adolescent Psychology 145, 162 (Allyn and Bacon 1976) (noting that "there is evidence ... to suggest that, for basic life decisions, the standards of the family carry more weight than the peer group when the two are in conflict").

132 See, for example, Ozorak, $28 \mathrm{~J}$ for the Scientific Study of Relig at 450 (cited in note 113) (reporting studies finding considerably greater influence from parents than from peers over adolescents' religious beliefs); David A. de Vaus, The Relative Importance of Parents and Peers for Adolescent Religious Orientation: An Australian Study, 18 Adolescence 147 (1983) (finding that parents had much greater influence than peers over religious beliefs). But see Dean R. Hoge, Gregory H. Petrillo, and Ella I. Smith, Transmission of Religious and Social Values from Parents to Teenage Children, $44 \mathrm{~J}$ Marriage \& Fam 569 (1982) (finding little evidence of value transmission from parents to children).

133 See, for example, Thomas J. Berndt, Transitions in Friendship and Friends' Influence, in Julia A. Graber, Jeanne Brooks-Gunn, and Anne C. Petersen, eds, Transitions Through Adolescence: Interpersonal Domains and Context 57, 63 (Erlbaum 1996) (noting that adolescents are less likely to be influenced by their friends when they have close relationships with their parents); Ozorak, $28 \mathrm{~J}$ for the Scientific Study of Relig at 451 (cited in note 113) (concluding that children are more likely to embrace their parents' religious beliefs where parents and child are emotionally close); Bernard Spilka, Ralph W. Hood, and Richard L. Gorsuch, The Psychology of Religion 76-92 (Prentice-Hall 1985) (contending that parents have a stronger influence on children's religious development than either peers or religious teachers, in part because of the depth of the emotional relationship between parent and child).

134 Ian McAllister, Religious Change and Secularization:The Transmission of Religious Values in Australia, 49 Sociological Analysis 249, 250 (1988) (citing studies emphasizing the "predominant influence of parents on adolescent religion, and more particularly, the importance of the general religious atmosphere of the home"); Hoge, Petrillo, and Smith, 44 J Marriage \& Fam at 578 (cited in note 132) (finding strongest evidence of value transmission where parents "had definite religious beliefs and agreed on them, and carried out conscious religious socialization in 
parents' religious group affiliation ${ }^{135}$ have also been found to correlate positively with the transmission of religious values to adolescent children.

While parents maintain a strong influence over the content of children's identity choices, it is through peer interactions that adolescents accomplish much of the work of identity formation. How the identity formation process unfolds, and how the choicemaking is perceived by the adolescent, will therefore have much to do with the identity of those peers and the nature of the interactions. After considering the role peers play in facilitating identity formation generally, I will take a closer look at how that process might be affected by the composition of those peers.

b) The role of peers. One of the most important changes that occurs in adolescence is the shift in relational focus from parents to peers. It is with peers that adolescents spend an increasing portion of their time ${ }^{136}$ and share confidences, ${ }^{137}$ and it is through these peer interactions that much of their identity development occurs. ${ }^{135}$

Peer interaction facilitates the development of individual identity along social, cognitive, and emotional dimensions. Most obviously, our

the home").

135 Ozorak, $28 \mathrm{~J}$ for the Scientific Study of Relig at 451 (cited in note 113) (concluding that children are more likely to embrace their parents' religious beliefs where the parents belong to a faith with a strong group identity). See also McAllister, 49 Sociological Analysis at 261 (cited in note 134) (suggesting that religious groups which "encapsulate their members in the life of the church through overlapping and reinforcing memberships will retain the commitment of their members more effectively" than those with a looser policy on membership and participation); Hoge, Petrillo, and Smith, $44 \mathrm{~J}$ Marriage \& Fam at 578 (cited in note 132) (suggesting that value socialization takes place in cultural subgroups more than in nuclear families).

136 B. Bradford Brown, et al, Parenting Practices and Peer Group Affiliation in Adolescence, 64 Child Dev 467, 467 (1993) (noting a significant shift in adolescents' reference group from parents to peers); Ritch C. Savin-Williams and Thomas J. Berndt, Friendship and Peer Relations, in S. Shirley Feldman and Glen R. Elliot, eds, At the Threshold: The Developing Adolescent 277, 27778 (Harvard 1990) (noting that the frequency of interactions with peers increases, as it decreases with parents, throughout adolescence); Grotevant, Adolescent Development in Family Contexts at 1113 (cited in note 112) (reporting dramatic drop in the time spent with family between the ages of nine and fifteen); Potvin and Lee, 43 Sociological Analysis at 134 (cited in note 113) (noting that one's peer group becomes salient in mid-adolescence, and therefore parental religious practice becomes less influential on adolescent religious practice).

137 Berndt, Transitions in Friendship and Friends' Influence at 57 (cited in note 133) (noting that the biggest change in friendships in adolescence is the emergence of intimate friendships in which personal information is openly disclosed); Savin-Williams and Berndt, Friendship and Peer Relations at 278 (cited in note 136) (suggesting that teenagers "are far more likely to be selfdisclosing and open, to 'tell everything' about the self, to friends than to parents").

138 B. Bradford Brown and Wendy Theobald, Learning Contexts Beyond the Classroom: Extracurricular Activities, Community Organizations, and Peer Groups, in Kathryn Borman and Barbara Schneider, eds, The Adolescent Years: Social Influences and Educational Challenges 109, 126 (Chicago 1998) (noting that adolescents "routinely turn to their peers for assistance" with the primary tasks of identity formation); Meeus and Dekovic, 30 Adolescence at 943 (cited in note 104) (reporting findings, based on adolescent self-reporting, that peers were named as the primary supports in the identity development process). 
choice of friends helps define who we are in a way that our involuntary association with our parents cannot. Who we choose as friends tells our broader social group something about our values, talents and tastes, ${ }^{139}$ and the way others perceive us affects how they relate to us. These interactions, in turn, affect how we perceive ourselves. ${ }^{140}$ Moreover, in the process of choosing friends, we learn something about what we enjoy and value. ${ }^{141}$ Disappointments in friendship may tell us as much about ourselves as about the erstwhile friend.

On the level of cognitive development, peer interactions facilitate the adolescent's ability to engage in reflection about her own identity. Because peer interactions are perceived as interactions among equals, they allow an adolescent to objectify her experiences, behaviors, values, and attitudes in a way that her interactions with her parents do not. $^{142}$ An adolescent can explore her own identity by talking to peers about her experiences, behaviors, and values, and by comparing herself (along these dimensions) to those peers. ${ }^{143}$ In this way, adolescents use their relationships with peers to scrutinize themselves, and this

139 Brown and Theobald, Learning Contexts Beyond the Classroom at 126 (cited in note 138) (suggesting that peer crowds offer adolescents provisional identities which "articulate all features of an identity in stereotypic form"); Grotevant, Adolescent Development in Family Contexts at 1115-16 (cited in note 112) (noting that the group stereotyping that goes on among adolescents in school helps children to understand alternative social identities available to them).

140 Erikson suggested that a central aspect of identity formation was reconciling one's own perception of self with the perceptions of others. Erikson, Identity: Youth and Crisis at 159-61 (cited in note 97).

141 Brown, Peer Groups and Peer Cultures at 179-80 (cited in note 128) (describing adolescents' search for a peer group whose attitudes and interests match their own as a piece of the identity exploration process).

142 See Grotevant, Adolescent Development in Family Contexts at 1115 (cited in note 112) (noting that the equality of authority among peers, as compared to between parents and children, helps adolescents learn to take another's perpective, as well as to negotiate to an agreement); Meeus and Dekovic, 30 Adolescence at 933 (cited in note 104) (noting that "[s]ince youngsters have no formal power over each other, interaction among peers is based on the principle of symmetry and equality"); Grotevant and Cooper, 29 Hum Dev at 85 (cited in note 97) (noting that, "[p]articularly in their friendships, preadolescents increasingly view themselves as distinctive persons in relation to others, with peers serving as external reference points that allow children to see how they are both similar and different from others"); Potvin and Lee, 43 Sociological Analysis at 132 (cited in note 113) (noting that the equality of authority among peers allows for an objective discussion of religious affiliation and identity that facilitates independence from adult rules). See also Jean Piaget, The Moral Judgment of the Child (Free Press 1948) (recognizing the importance of peer relationships to the facilitation of the development of a child's moral reasoning).

143 Savin-Williams and Berndt, Friendship and Peer Relations at 279 (cited in note 136) (" $[B]$ y allowing oneself to become vulnerable around a coequal, adolescent friends share with one another their most personal thoughts and feelings, become sensitive to the needs and desires of others and in the process acquire a deep understanding of the other and the self."). See also Berzonsky, A Process Perspective on Identity and Stress Management at 198 (cited in note 105) (finding that moratoriums looked to others for ideas about alternatives to consider). 
peer-facilitated objectification eventually evolves into a more internalized ability to self-reflect. ${ }^{144}$

And finally, forming close relationships with peers provides a kind of emotional support that helps adolescents make the transition from parental dependence to adult independence. ${ }^{145}$ Adolescents practice separating from their parents by attaching more intensely to peers, from which relationships they can gradually distance themselves as they become increasingly comfortable with their independence. Peers offer transitional support, in part by simply offering the opportunity for close relationships with those other than parents, ${ }^{146}$ and in part by reacting less personally, and therefore less judgmentally than parents, to exploration of options viewed as departures from parental wishes.

Note that all three of these forms of peer influence bear primarily on the process of identity formation, rather than on the substance of choices made by the adolescent. Although direct peer influence over important choices is greatly feared by parents and the public at large, this fear appears to be exaggerated. As already mentioned, studies suggest that adolescents are more influenced by parents than peers when they make important, far-reaching choices, ${ }^{197}$ and to the extent

144 Potvin and Lee, 43 Sociological Analysis at 142 (cited in note 113) (describing lateadolescent religious practice as "more autonomous" than earlier practice, because it has been "co-constructed" with peers).

145 Kroger, Identity in Adolescence at 55 (cited in note 91) (noting, in the context of psychoanalytic "object relations" theory, that "it is the peer group which, under optimal conditions, supplies support during the loss of [the] childhood psychic structure," namely the "internalized parental image" that constitutes the core of the child's identity prior to adolescence); Meeus and Dekovic, 30 Adolescence at 933 (cited in note 104) (noting that children's achievement of independence from their parents is accomplished through the "restructuring [of] their network of significant others," during which "friends and later a partner ... [gradually] take the place of the parents as the most important reference persons"); Brown, Peer Groups and Peer Cultures at 179-80 (cited in note 128) (describing adolescents' temporary dependence on their peer groups as a means of transitioning from psychological dependence on parents to "fully autonomous" functioning); Savin-Williams and Berndt, Friendship and Peer Relations at 277 (cited in note 136) ("For many adolescents relations with friends are critical interpersonal bridges that move them toward psychological growth and social maturity.")

146 Savin-Williams and Berndt, Friendship and Peer Relations at 278 (cited in note 136) ("[F]riends increase one another's self-esteem; provide information, emotional support, and advice; and help and support one another."); M. Luisa Pombeni, Erick Kirchler, and Augosto Palmonari, Identification with Peers as a Strategy to Muddle Through the Troubles of the Adolescent Years, 13 J Adolescence 351 (1990) (describing the reliance on interactions with peer groups as a source of support in dealing with a range of problems confronted in adolescence); Fasick, 19 Adolescence at 150 (cited in note 131) (describing the "extension of strong emotional bonds to peers in preparation for the movement of the closest emotional relationships to one's family of procreation").

147 See notes 131-33 and accompanying text. Some of these studies also emphasize that, by late adolescence, individuals rely more on their own judgment than on the advice of either parents or peers. See, for example, Hamachek, Development and Dynamics of the Self at 162 (cited in note 131) (teenagers are more likely to rely on their own judgment than on the advice of either peers or parents). See also Savin-Williams and Berndt, Friendship and Peer Relations at 278 
adolescents take direction from their peers, that direction tends to be limited in its scope and duration. ${ }^{148}$ Finally, whatever influence peers exert over these choices is at least as likely to have prosocial as antisocial effects. ${ }^{\mathrm{K} / 9}$

Far more important than this direct influence over substantive choices ("I will do $x$ because my peers do so") is their influence over the process through which an adolescent makes choices ("I will do $x$ because of what I have decided about myself, as a result of my interactions with my peers"). This influence on process is also a matter of great concern to parents, for it too can inspire a departure from parental values, albeit more indirectly. It is reasonable to expect this threat to increase with the diversity of the peer group, not because unlike peers will simply inspire an adolescent to follow along, but rather because they may inspire, through the social, cognitive, and emotional effects mentioned, a broader process of exploration that produces deeper questioning of values inherited from parents and more careful consideration of how those values fit with the adolescent's emerging sense of self. Whether the state has some countervailing interest in promoting precisely this process of exploration is the important question unaddressed in the debate over allocation of educational control.

(cited in note 136) (noting that in self-report studies of adolescent influences, "a significant number of adolescents 'abandoned the provided response categories and spontaneously added 'myself,' 'personal opinion,'... to emphasize independent choice"); Jean Piaget, The Intellectual Development of the Adolescent, in Gerald Caplan and Serge Lebovici, eds, Adolescence: Psychological Perspectives 22 (Basic 1969) (suggesting that formal operational thought, generally achieved by mid-adolescence, equips individuals to disagree with others and to engage in an independent action based on one's own principles). Of course, this observation begs the question of whence those independent judgments were derived.

148 Donna Rae Clasen and B. Bradford Brown, The Multidimensionality of Peer Pressure in Adolescence, $14 \mathrm{~J}$ Youth \& Adolescence 451, 460 (1985) (describing peer pressure as a contextdependent force that varies with the type of adolescent behavior); Fasick, 19 Adolescence at 150 (cited in note 131) (noting that conformity to peer group pressure "peak[s] at about 12 to 15 years and then declines"); John C. Coleman, Friendship and the Peer Group in Adolescence, in Joseph Adelson, ed, Handbook of Adolescent Psychology 408, 422 (Wiley \& Sons 1980) (noting that susceptibility to group pressure gradually decreases after the eleven to thirteen age range).

149 See, for example, Clasen and Brown, $14 \mathrm{~J}$ Youth \& Adolescence at 465-67 (cited in note 148) (recording adolescent perceptions that peers exerted more pressure to behave well, as defined by school authorities, than to behave badly); Paul A. Osterrieth, Adolescence: Some Psychological Aspects in Caplan and Lebovici, eds, Adolescence 11, 18-19 (cited in note 147) (discussing the ways in which peers are important to "the seeking and the affirmation of self").Applying this pro/antisocial distinction in our context is complicated. In one sense, these studies counter parental fears that exposure to unlike peers will produce bad behaviors and attitudes. They also suggest that children with strong values, tied with their religious upbringing, may influence unlike peers as much as those unlike peers are likely to influence them. At a general level, however, parents object not because their children will be exposed to antisocial values and choices, but simply because they will be exposed to different values. See, for example, Yoder, 406 US at 211 (noting Amish parents' objection to their children's high school attendance, in part because "it places Amish children in an environment hostile to Amish beliefs with increasing emphasis on competition in class work and sports"). 
c) Which peers? Parents seeking control over their children's educational associations are not seeking to prevent peer interactions from occurring altogether - a parenting practice that courts might well find abusive or neglectful-but rather to control the nature, extent, and composition of those peer interactions. In this way, parents frequently seek to put the child's peer interactions in the service of reinforcing sameness. Where a parent limits the pool of peers to those raised in the parent's own traditions, the child's choice of peers, the self-reflection facilitated by peers, and the emotional support provided by peers in that pool will all help to point the child in the direction of the parent's ideologies and affiliations. ${ }^{150}$

While these relationships with like peers still offer the child an opportunity to "try on" an identity by acting independently of parents and reflecting on that identity through peer interactions, this opportunity for exploration will be more narrowly circumscribed. The child's choice of friendships may offer some range in personality types, but not in value structures or long-term ambitions. The child's conversations with friends may allow her to understand her own value structure better, but they will be less likely to push her to question her own choices because they will not offer her alternative values and plans to compare with her own. The emotional support provided by these similar peers will help her make the transition to independence, but, at least typically, will not extend to support a serious questioning of the common values of the community.

Although most would consider a child's embrace of her parents' beliefs, and particularly their religious faith, a valuable, or at least a neutral, end for the child, ${ }^{151}$ we should consider whether our valuation of that end should be tied to how it is achieved. Returning to Erikson and Marcia, we might worry about a "foreclosed" individual, whose sense of identity was an unthinking adoption of parental beliefs, driven by a desire to please, or to avoid disapproval. As discussed above, some of the literature suggests that this path to identity commitment may produce less healthy adult functioning. ${ }^{152}$ Even without

150 Compare Phinney and Rosenthal, Ethnic Identity in Adolescence at 155 (cited in note 119) (reporting findings suggesting that the more comprehensive and cohesive the subculture's presence in a child's life, the greater the child's ethnic identity). Note that, for the sake of clarity, this discussion assumes, artificially, that the values of the adolescent's peers remain fixed while those of the adolescent being discussed are in the process of development. In reality, of course, the peers would be simultaneously undergoing the same process of identity formation.

151 This conclusion could be grounded on a perception that sharing a parent's religious affiliation will promote children's well-being, or on a more theoretical commitment to a pluralistic society.

152 See, for example, Ryan, Rigby, and King, $65 \mathrm{~J}$ Personality \& Soc Psych at 594 (cited in note 118) (reporting findings suggesting that children whose internalization of their religious identity is driven by a sense of obligation and outside expectations show a higher rate of negative psychological adjustment). 
getting into the soft world of well-being indicators, we might worry that such a basis for belief and values is inconsistent with assumptions about autonomous choice that undergird common conceptions of our exercise of rights, including our free exercise right. In contrast, we might expect that facilitating an adolescent's interaction with a wider range of peers might produce a more thorough exploration of her identity which, in turn, could produce a sense of self-understanding and self-authorship associated with more autonomous decisionmaking. ${ }^{1.5}$

Not surprisingly, in the context of religious development, there is no direct proof that increased interaction with unlike peers produces more autonomous decisionmaking. ${ }^{1.4}$ This is in part due to the fact that the law has protected parents' right to shield their children from this exposure, both through the operation of general policies ceding control over educational placements to parents, and through express exemptions from more integrative policies authorized by the courts. It is also due in part to the fact that even where the law has done nothing to facilitate ideological segregation, self-selection in communities and in high school friendships ${ }^{135}$ tends to reduce the opportunities for peer interactions among diverse individuals. There is, however, ample evidence of the more general connection between the opportunity for exploration of different identity choices and greater independence in choicemaking. A diverse set of peers can play an important role in facilitating this explcration process. There is also evidence in analogous contexts that structured interaction with unlike peers has significant effects, not only on perceptions of others, but also on perceptions of self. ${ }^{1.5}$

153 Berzonsky, A Process Perspective on Identity and Stress Management at 200 (cited in note 105) (noting positive correlation between achievements and moratoriums, on the one hand, and those with an "internal locus of control," that is, a perception that they are in control of relevant outcome in their lives).

154 Again, I emphasize that while the primary project of this Article is to apply psychologists' current understanding of development to a legal debate, a secondary project is to spur psychologists to study more directly the developmental issues that bear on the debate.

155 Brown, Peer Groups and Peer Cultures at 180 (cited in note 128) (noting that adolescents, left to their own devices, will seek out peers who are similar to themselves); Savin-Williams and Berndt, Friendship and Peer Relations at 283-84 (cited in note 136) (speculating that the increasing similiarity among friends in adolescence may be caused by a combination of community and educational segregation, self-selection in activities, and a preference for familiar social interactions).

156 See, for example, Jeanne Watson and Ronald Lippitt, Cross-Cultural Experience as a Source of Attitude Change, $2 \mathrm{~J}$ Conflict Resolution 61, 66 (1958) (concluding that exposure to a foreign culture frequently prompted self-reflection about the traveler's own culture). See also Elizabeth W. Leonard, Attitude Change in a College Program of Foreign Study and Travel, 45 Educ Rec 173, 180 (1964) (concluding that structured orientation program facilitated influence of foreign travel on attitudes). 
Parents fear that facilitating these interactions will undermine their ability to foster their children's sense of affiliation and commitment to the parents' community, particularly their religious community. If the trade-off is inevitable, courts and policymakers must choose between the state's interest in facilitating a child's more thorough, reflective, identity exploration on the one hand, and the parents' interest in cultivating the child's connection with their own religious community and worldview on the other. In Part III, I suggest that, at a minimum, the courts have an obligation to confront this trade-off in their constitutional analysis of parents' claims. I then go on to suggest an approach, grounded in the developmental empirics, that could minimize the trade-off.

\section{IMPLICATIONS}

Focusing on adolescent development does not suggest simple answers, but it does reframe the question. A primary developmental project of adolescence is working out identity issues, and a primary aspect of the developmental process in adolescence is peer interaction. Because identity formation is such an important preparatory step toward adulthood, ${ }^{15}$ and because peers play such an important role in assisting adolescents to take that step, those with the responsibility for children's development-state and parent alike-have every reason to be concerned about who those peers are and the nature of those interactions.

The parents are well attuned to these concerns. Indeed, their interest in controlling these peer interactions drives many of their placement decisions and much of their litigation in the educational setting. Controlling these interactions, parents have concluded, is an important tool for controlling the development of their children's group identification, spiritual beliefs, and value systems. Recent legislative trends, however, suggest that states are paying inadequate attention to their countervailing interest in exerting control over a child's peer environment. The failure to take these countervailing interests into account is more starkly documented in the courts' review of parents' free exercise challenges to state educational policies that have an ideologically integrative effect. There, the courts focus woodenly on the state's interest in the substance of the curriculum-pondering the importance of teaching children information and methods of thinking-abstracted from any consideration of the company in which

157 Ruthellen Josselson, The Theory of Identity Development and the Question of Intervention, in Sally L. Archer, ed, Interventions for Adolescent Identity Development 12-13 (Sage 1994) ("Because identity forms the foundation of adult life, as a society we have a large stake in seeing that this takes place as optimally as possible."). 
these lessons are learned. As a result of this omission, courts undervalue the state's interest in keeping children together in school and overvalue the state's interest in curricular control.

In my attempt to take better account of these values, let me begin by reviewing the nature of the state's interest in facilitating unlike peer interactions, as highlighted by the developmental literature. The message from this literature is not that peers will constitute the primary influence over the choices an adolescent ultimately makes, especially on issues of long-term importance. Studies suggest that parents have more outcome influence than peers on these important choices. ${ }^{158}$ The peer influence is more subtle: interaction with peers affects the process by which choices are made, the adolescent's attitudes about those choices, and how those choices fit with the adolescent's evolving sense of self. By facilitating unlike peer interactions, the state can stimulate adolescents' engagement in a process of identity exploration that can yield benefits for these adolescents, regardless of the ultimate choices they make.

Consider the example of an Amish adolescent who embraces her family's religion as her own. She might reach this point through a process of exploration and resolution (producing, in Marcia's words, an "achieved" identity status) or she might reach this point through an unreflective fulfillment of expectations (producing "foreclosure"). Both processes can produce Amish adults, but those two adults will perceive their choice to remain Amish differently, and those differences will, in turn, affect their perception of themselves and of the values adopted. To oversimplify for the purpose of clarity, a developmentalist would predict that an "achieved" Amish person would have a real understanding of the opportunity to exit, would nevertheless choose not to exit, and would appreciate why she made that choice and how it fits with the rest of her sense of self. A "foreclosed" Amish person, in contrast, would have no real understanding of what it would mean to exercise other options, and would feel compelled by various social forces to stay Amish, regardless of the fit. ${ }^{160}$

158 See text accompanying notes 131-33.

159 See text accompanying note 103.

160 Of course, a process that makes the prospect of exit meaningful is also a process that makes exit more likely, but, for many, exposure to the process of exploration produces a changed perception of one's religious choices and religious identity, without a change in religious affiliation. Potvin and Lee, 43 Sociological Analysis at 142 (cited in note 113) (suggesting that, after a period of "co-construction" of religious values with peers at roughly fifteen or sixteen, the seventeen or eighteen-year-old will demonstrate greater autonomy in the practice of religion, even if he confirms the beliefs and experiences of his parents); Fowler, Stages of Faith at 9-15 (cited in note 121) (describing advancements in faith inspired by an exploration process that furthers critical reflection and leads to a maturation of faith within the same belief system). It is worth noting that even some Amish communities create an opportunity for identity exploration through "Rumspringa," or "running around," during which adolescents, beginning at roughly six- 
The state might wish to promote identity achievement for two interrelated reasons. First, there is considerable support for the Eriksonian equation of identity achievement with psychological health and successful adult functioning. ${ }^{161}$ A state interested in maximizing the productive functioning of its adult citizenry-frequently identified as a compelling state interest ${ }^{162}-$ might well seek to promote a process of choicemaking that correlates with such positive mental health outcomes. I am unwilling to argue, however, that a state's interest in facilitating adolescents' identity exploration should be grounded on these well-being indicators, for a number of reasons. First, quantifying wellbeing, let alone identifying the causes of that well-being, is a highly elusive enterprise in any context. Second, such a quantification is likely to be heavily affected by context. Indeed, there is some evidence to suggest that a foreclosed identity status can facilitate successful functioning in cultures that offer individuals few options. ${ }^{163}$ Finally, this second, pragmatic qualification supports a more principled reluctance to embrace well-being indicators that cannot be easily disentangled from qualitative judgments about the merits of various cultural and religious practices and beliefs. Because psychologists' assessments of what constitutes healthy functioning will inevitably reflect the values of their own culture, which will generally be the dominant culture, tying educational policy to these indicators of well-being will privilege the dominant culture's values in a manner that disserves our commitment to a multicultural society. In the absence of more unequivocal data suggesting a marked difference in the quality of basic functioning between individuals with achieved and foreclosed identity statuses across cultures, I would not favor tying the state's interest in facilitating exploration and identity achievement to these well-being indicators.

The same literature, however, suggests another reason a state might wish to promote identity achievement, a reason tied to the state interest in promoting democratic participation, which is also frequently identified as a compelling interest. ${ }^{164}$ The literature suggests

teen, are allowed to experiment with non-Amish ways, including, in some communities, drinking, drugs, and sex. Most, but not all, of these adolescents eventually decide to stay within the community and be baptized as Amish.

161 See text accompanying note 105.

162 See, for example, Yoder, 406 US at 221 (acknowledging that education "prepares individuals to be self-reliant and self-sufficient participants in society"); Prince v Massachusetts, 321 US 158, 168 (1944) ("A democratic society rests, for its continuance, upon the healthy, wellrounded growth of young people into full maturity as citizens.").

163 See note 112 and accompanying text.

164 See, for example, Yoder, 406 US at 221 (acknowledging state's interest in providing the education "necessary to prepare citizens to participate effectively and intelligently in our open political system if we are to preserve freedom and independence"). 
that identity exploration tends to produce a greater sense of autonomy in subsequent decisionmaking. That is, those who make commitments after engaging in a process of identity exploration are more likely to experience choicemaking as a deliberate, self-reflective, selection among options and are more likely to perceive themselves as the authors of their own choices. ${ }^{165}$ The identity development literature frequently equates this sense of autonomy with emotional and functional well-being, ${ }^{166}$ but the state need not rely on such outcome measures to justify its interest in nurturing a sense of autonomy among adolescents. The state might seek to cultivate this sense of selfdetermination in its citizens in order to promote their effective democratic participation both as voters and, more indirectly, through their exercise of individual rights. Embracing a religious faith or other significant values after a process of exploration and resolution arguably better comports with our conception of what constitutes the exercise of civil rights in our constitutional system than does embracing the same faith or values out of an unreflective sense of obligation.

Whether self-reflective choicemaking is important to the functioning of our democracy is, itself, of course, a question. Classic liberal theory clearly assigns autonomy a central role, ${ }^{167}$ and even political lib-

165 Philosophers and psychologists both use the term "autonomy" to capture selfdetermined action, but the use of the term in the two disciplines seems to take on a somewhat different emphasis. While philosophers often focus on the cerebral aspect of choicemaking (asking whether the individual engaged in a process of critical reasoning based on good information about a full range of options in making her choices about which values and communities to embrace), the psychologist focuses more on the subjective experience of choicemaking and the detail of the process producing that experience. In particular, the developmental psychologist asks whether the individual had an opportunity to explore alternatives by, among other things, talking to peers about a range of possible roles and by interacting with peers who have assumed some of those alternative roles. Compare Fowler, Stages of Faith at 174-83 (cited in note 121) (suggesting that the movement from a stage three "synthetic-conventional faith" to a stage four "individuative-reflective faith" during adolescence can be inspired by experiences or encounters with perspectives that promote critical reflection about one's own beliefs). In assessing the extent to which autonomy in choicemaking is actually achieved, psychologists look to the subjective experience of that choicemaking, asking whether the individual perceives her actions as selfdetermined and true to the comprehensive sense of self she has generated through the exploration process. Ryan, Rigby, and King, $65 \mathrm{~J}$ Personality \& Soc Psych at 594 (cited in note 118) (characterizing as autonomous action perceived by the actor as volitional and "emanating from himself or herself').

166 See Meeus and Dekovic, 30 Adolescence at 932 (cited in note 104) (summarizing literature associating identity achievement and moratorium with positive characteristics including autonomy). This same correlation between sense of self-efficacy and well-being is also noted in the separate psychological literature of "attribution." See, for example, Virginia C. Crandall and Beth W. Crandall, Maternal and Childhood Behaviors as Antecedents of Internal-External Control Perceptions in Young Adulthood, in Herbert M. Lefcourt, ed, 2 Research with the Locus of Control Construct: Developments and Social Problems 53,53-54 (Academic 1983) (summarizing literature suggesting that an internalized locus of control facilitates positive functioning in learning, achievement, interpersonal skills, emotional adjustment, and contentment).

167 See text accompanying notes $64-69$. 
eralism, which attempts to define a common political core that does not demand that all citizens recognize autonomy as a supreme value, nevertheless makes important assumptions about citizens' capacity to engage in autonomous decisionmaking. ${ }^{168}$ Our cases, too, capture a concept of rights that appears to associate their exercise with autonomous action. ${ }^{169}$ Indeed, a classic justification for circumscribing children's rights appeals to their reduced capacity to engage in autonomous decisionmaking. ${ }^{170}$ If our expectations for citizens' political participation and exercise of civil rights are grounded in assumptions about citizens' capacity to act autonomously, as many suggest they are, encouraging identity exploration through unlike peer interactions offers a promising means of fulfilling these expectations.

Promoting the development of children's capacity for autonomy is easy to embrace in the abstract. Courts and legislatures might nevertheless conclude that this goal is insufficiently compelling to justify constraining parents' control over their children's associations, particularly where those associational choices are driven by religious beliefs. In the context of parents' free exercise claims, courts might well decide that whatever could be gained by facilitating interactions with unlike peers is outweighed, as a matter of constitutional mandate, by the potential loss to parents of their ability to transmit religious values to their children. ${ }^{171}$ The courts' analysis does not, however, reflect any considered choice between conflicting interests in peer control. In-

168 See note 70 and accompanying text.

169 See, for example, Prince, 321 US at 165 (describing the state's interest in protecting the welfare of children as "the interest of youth itself, and of the whole community, that children be ... given opportunities for growth into free and independent well-developed men and citizens").

170 See, for example, Ginsberg $v$ New York, 390 US 629, 649-50 (1968) (Stewart concurring) ("[A] State may permissibly determine that, at least in some precisely delineated areas, a child ... is not possessed of that full capacity for individual choice which is the presupposition of First Amendment guarantees."). See also Bellotti v Baird, 443 US 622, 634 (1979) (pointing to children's "inability to make critical decisions in an informed, mature manner," as one of three justifications for refusing to equate their constitutional rights with those of adults).

171 See Yoder, 406 US at 232 ("[I]t seems clear that if the State is empowered, as parens patriae, to 'save' a child from himself or his Amish parents by requiring an additional two years of compulsory formal high school education, the State will in large measure influence, if not determine, the religious future of the child."). The interest in avoiding this trade-off also probably accounts, at least in part, for the theorists' inclination to confine the state's educational control to the substance of children's curriculum. See Part I.C. Unlike the courts, these theorists stress the importance of ensuring that children grow up to make independent choices rather than simply to embrace their parents' religious values because they lack the capacity to do otherwise. But while these theorists have high ambitions for the state's ability to ensure the development of autonomous thinking in its students, they, like the courts, propose to leave the state ill-equipped to achieve that aim. In the end, the courts and theorists embrace roughly the same approach: Courts limit state control to substance, without regard to how this may affect the state's ability to facilitate students' autonomous choicemaking, and the theorists limit state control to substance on the unsupported hope that this will be sufficient to allow students to develop the capacity for autonomous choicemaking. Both leave associational control with the parents in the interest of avoiding interference with parents' transmission of religious values. 
stead, the court fails to take any account at all of the state's interest in facilitating interactions with unlike peers.

The omission is particularly remarkable, in light of the courts' willingness to recognize this interest in other contexts, particularly the context of state attempts to restrict religious proselytizing by students. $^{172}$ In that context, the courts have emphasized the benefit high school students in particular can derive from interactions that force them to engage with students with whom they are likely to disagree. In the words of one court:

Most importantly, the mission of public education is preparation for citizenship. High school students ... must develop the ability to understand and comment on the society in which they live and to develop their own sets of values and beliefs. A school policy completely preventing students from engaging other students in open discourse on issues they deem important cripples them as contributing citizens. Such restrictions do not advance any legitimate governmental interest. On the contrary, such inhibitions on individual development defeat the very purpose of public education in secondary schools. ${ }^{173}$

The decisions in these cases carry two strong messages that bear noting in our consideration of parents' attempts to block their children's exposure to all or part of public education: first, interaction among peers with different viewpoints is valuable for children's development into effective adult citizens, and, second, the value of these interactions increases with children's age, particularly as they near adulthood. ${ }^{174}$

172 The cases considering attempts to achieve racial integration in education offer another example. Compare Regents of the University of California v Bakke, 438 US 265, 312 n 48 (1978) (recognizing, in the higher education setting, the educational value of interaction with a diverse group of peers).

173 Rivera v East Otero School District R-1,721 F Supp 1189, 1194 (D Colo 1989) (emphasis added). See also Tinker v Des Moines Independent Community School District, 393 US 503, 512 (1969) (contending that "personal intercommunication among the students ... is not only an inevitable part of the process of attending school; it is also an important part of the educational process"); Clark v Dallas Independent School District, 806 F Supp 116, 121 (N D Tex 1992) ("A blanket prohibition on high school students' expression of religious views and even proselytizing on campus is unconstitutional and contrary to the purpose of secondary schools."); Thompson v Waynesboro Area School District, 673 F Supp 1379, 1387 (M D Pa 1987), quoting Tinker, 393 US at 508-109 ("Any word spoken, in class, in the lunchroom, or on the campus, that deviates from the views of another person may start an argument or cause a disturbance. But our Constitution says we must take this risk ... and our history says it is this sort of hazardous freedom - this kind of openness - that is the basis of our national strength and of the independence and vigor of Americans who grow up and live in this relatively permissive, often disputatious, society.").

174 The courts' assessment of the harms and benefits associated with student proselytizing make clear distinctions based on age. For children in elementary school, the courts focus on children's likely confusion about the source of the religious viewpoint, and conclude that prohibiting such proselytizing is appropriate. See, for example, Bell v Little Axe Independent School District 
In the context of student proselytizing, the educational interest in facilitating interactions with unlike peers is juxtaposed with the school's interest in maintaining order and avoiding the erroneous attribution of student viewpoints to the school. ${ }^{175}$ In our context, the counterweight may well be heavier. If a trade-off between the state's interest in developing children's capacity for independent choicemaking and parents' interest in transmitting their religious values to their children is inevitable, we might well conclude that the Constitution requires the courts to privilege these parental interests over those of the state. With this much potentially at stake, however, it is incumbent upon the courts to at least own up to the choice they are making, a choice between two aspects of our free exercise conception that are generally assumed to be mutually compatible rather than in conflict. It is a choice between a conception of the Free Exercise Clause that focuses on facilitating a child's ability to grow up and make independent decisions on matters of religion, and a conception that focuses on fostering a child's sense of affiliation that would motivate her to assert the right. One interpretation bolsters the child's chance to choose at the possible cost of depleting her religious connection, the other bolsters the chance of religious connection, at the cost of some opportunity for the exercise of personal choice. Where the courts choose to privilege religious connection over the facilitation of autonomous choicemaking, this preference should be made plain in their decisions.

No. 70, 766 F2d 1391, 1404 \& $\mathrm{n} 11$ (10th Cir 1985) (citing expert psychological support for the conclusion that "[e]lementary schoo'children are vastly more impressionable than high school or university students and cannot be expected to discern nuances which indicate whether there is true neutrality toward religion on the part of a school administration"); DeNooyer v Livonia Public Schools, 799 F Supp 744, 751 (E D Mich 1992) (finding reasonable the school authorities' concern that students "would infer the school's endorsement of the speech presented during class," and noting that "[t]he maturity level of the second grade students was a significant concern"). For children in high school, however, the court dismisses the risk of confusion and focuses on the benefits children derive from exposure to one another's ideas. See, for example, Gregoire v Centennial School District, 907 F2d 1366, 1381 (3d Cir 1990) ("Centennial has made a decisive judgment concerning the maturity of its high school and junior high school students and their ability to understand that granting access to a group does not imply endorsement of the message presented."). These cases take their lead from Board of Education of the Westside Community Schools (Dist. 66) v Mergens, 496 US 226, 228 (1990) (syllabus) (stating that "[t]here is a crucial difference between government and private speech endorsing religion, and, as Congress recognized in passing the [Equal Access] Act, high school students are mature enough and are likely to understand that a school does not endorse or support student speech that it merely permits on a nondiscriminatory basis").

175 See, for example, Hedges v Wauconda Community Unit School District No. 118, 9 F3d 1295 (7th Cir 1993) (considering school district's contention that the policy restricting distribution of religious literature was tied to a concern that students would perceive the distribution as a school-endorsed activity); Thompson, 673 F Supp at 1388-89 (noting that among school authorities' concerns were that "the distribution of the papers [would create] congestion of traffic in the school's hallways and disruption of school activities" and that "parents would object to their children being exposed" to the religious materials and that a failure to regulate distribution would subject them to Establishment Clause challenges). 
But the developmental literature offers more, I think, than a better understanding of which interests are facilitated through which means. It also suggests a way to minimize the trade-off between the two important interests-the interest in developing children's capacity to exercise autonomous choice and the interest in transmitting a parent's religious values and affiliations to her child - that we have considered. The literature provides a more sophisticated account of the means as well as the timing of a child's development bearing on these two interests, and this account, in turn, suggests a means of enhancing both.

In allocating parental control between parent and state, the law treats childhood as monolithic and for the most part only accounts for development by distinguishing childhood from adulthood. When all of childhood is treated as the same, trade-offs among developmental influences will inevitably be perceived as abundant, for anything that influences a child is likely to be in direct competition with every other influence. Of course, we know, without resort to the literature, that development is ongoing through childhood, and that influences change over the course of that development. Indeed, influences can build on one another rather than clash, and some influences occur early in life and exert long-lasting effects, despite a child's lack of ongoing exposure to that influence.

There is no particular reason to think that the factors that influence a child's development of group identity and spiritual values are necessarily in competition with the factors that influence a child's development of a capacity for autonomous decisionmaking, despite the fact that both sets of influences may be felt by a child sometime in adolescence. Indeed, I find considerable support in the literature for the conclusion that a child could get the benefit of both types of influences if these influences are allowed to be temporally disaggregated.

I have noted that the literature suggests that the primary source of a child's values, especially important values affecting long-term choices and group affiliations, is her parents. Peers play a considerably larger role, however, in an adolescent's process of internalizing those values as the adolescent shifts from a conception of parental authority to one of personal independence. I also noted evidence suggesting that group identity formation is well advanced by middle adolescence, ${ }^{170}$ whereas the more self-focused, value-selecting aspect of identity work

176 For the most identifiable groups, exposure to a diverse group of peers in high school may serve to reinforce, rather than undermine, group identity. See Brown, Peer Groups and Peer Cultures at 183 (cited in note 128). Compare Kahn, A Study of the Development of Religious Prejudice in Children at 116-33 (cited in note 124) (finding that Indian children attending religiously integrated schools developed a sense of religious identity earlier than those children who attended segregated schools). 
tends to occur later in adolescence and even into early adulthood. Together, differences in the source and timing of the two sets of influences suggest that an age-sensitive approach to the balancing of state and parental interests might yield a result that better serves both interests: The law's absolute deference to parental control of a child's associations could be modified in late adolescence to account for the state's distinct interests in exerting some associational control during those years.

While the cases on which we have focused make no intrachildhood age distinctions, we have seen, in the cases considering student proselytizing activity, the courts' willingness to make age-based distinctions about the appropriateness of unlike peer interactions. Indeed, in that context, courts are willing to show less deference to parents' desire to protect their children from unlike peer interactions as those children mature. ${ }^{17}$ These cases reflect a greater level of attention to children's changing needs and roles, noting the decreased vulnerability to confusion or trauma associated with ideological discussions among peers and the increased value of these interactions as children approach adulthood.

A strong developmental case can be made for the proposition that the state's interest in facilitating interactions with ideologically unlike peers is greatest when minors reach late adolescence, and that this waxing of the state interest is accompanied by the waning of the parental interest in blocking those interactions. In doctrinal terms, the burden on the parents' religious exercise can be said to be reduced when their child reaches late adolescence, because they have already had a significant opportunity to transmit religious values and affiliations to their child, and the threat to successful value transmission that can come at this stage from interaction with peers who do not share those values and affiliations is relatively minor. Conversely, the state's interest in preparing children for independent choicemaking (whether that interest is limited to the political realm, or defined to include choicemaking in all aspects of life ${ }^{178}$ ) is at an all-time high, because it is in late adolescence that children's interactions with unlike peers are most likely to produce the identity exploration that can foster this independence. Of course, exposure to unlike peers does not just serve the interests of the child whose parents resist such exposure. The peers with whom the erstwhile segregated child interacts will also benefit from the expanded opportunity for identity exploration.

177 See note 175 .

178 See note 70 and accompanying text for a brief discussion of the disagreement between political and comprehensive liberals on this point. 
Before going on to consider how this disaggregation of developmental influences might be accomplished, I want to insert two qualifications: First, my contention that these influences can be disaggregated is necessarily speculative. This is in part because developmentalists have never seen a reason to frame the question in these terms and in part because the law has never given them a good opportunity to study the question. As long as the law rests associational control in the hands of parents alone, the harms and benefits of doing otherwise cannot be tested. ${ }^{177} I$ therefore build my argument by applying what is known about child development to the unknown, in the hope that this informed speculation will push lawmakers to reconsider their assumption that the trade-off is inevitable, and developmentalists to provide the empirical evidence that will help them do so.

Second, I want to emphasize that my message is not one of absolutes. I am not suggesting that the opportunity to engage in identity exploration and to develop the capacity for autonomous decisionmaking is an all-or-nothing proposition either facilitated or precluded depending upon whether an adolescent interacts with sufficiently unlike peers. Instead, I argue that adolescents' interactions with peers who hold different values and engage in different practices is one important piece of a child's identity formation process that will help push her in the direction of autonomous choice. Interactions with unlike peers will no more single-handedly guarantee the development of this capacity than reading Shakespeare will guarantee the development of creativity or greater wisdom about the ways of the world. I have kept things simple to make the point that facilitating unlike peer interactions, like teaching great poetry, adds something important to a child's education.

One notable example of this oversimplification is my use of the terms "unlike" and "ideologically diverse," which I use interchangeably to capture the range of peers from whom parents seek to shield their children because of their perceived differences in ideology, values, and beliefs. Of course, peers can be like and unlike one another in an infinite number of ways. I focus on differences in viewpoint and values, for it is along these dimensions, which bear most directly on the exercise of rights and democratic participation, that the state's interest in adolescent identity development is greatest. I focus more particularly on differences in religious values and beliefs, both because it is along these lines that parents and schools most consciously distinguish themselves, and because the enhanced constitutional protection

179 While we can learn something from families whose parents voluntarily arrange their children's education according to this model (controlled and religiously homogenous in their younger years, then integrated with unlike peers sometime in high school), the differences between a voluntary and involuntary arrangement seem considerable. 
afforded to religious choices has supported this segregation. The fact that like and unlike are not absolute concepts would make the state's job more complicated in execution, but it need not obscure the goal, which is to facilitate interaction among peers with a broad range of viewpoints and experiences bearing on matters of importance.

Assuming that I am right in contending that parents' interests in transmitting their values and beliefs and the state's interest in facilitating autonomous choicemaking can both be served by reserving the state's associational control until late adolescence, there are various ways the influence split could be put into effect. At one extreme, the state could eliminate all exemptions from school attendance requirements, or even compel public school attendance or some other form of associational activity with unlike peers (such as a period of national service) in the last one or two years of minority. ${ }^{180}$ Such compulsory public education might be applied universally, or perhaps as a form of compensatory education for children, such as those who had been home schooled, whose peer exposure had been most dramatically circumscribed. ${ }^{181}$ The diminution of parental burdens and the enhancement of the state's interest in these last years of minority provide a basis for limiting the application of the holdings in both Pierce and Yoder to children under sixteen or seventeen years of age. ${ }^{10}$

The shift of control from parent to state suggested here is relatively minor: until sixteen or seventeen, parents would have the full level of educational control protected in Pierce and Yoder, and even after this age parents would still have legal authority over all other aspects of the child's religious upbringing. The state could compel a kind of compensatory education to make up for the restrictions placed on peer interactions, but it would otherwise be required to defer to parental decisionmaking. Indeed, as I argue below, parents could have broad authority to exempt their children from particular curricular

180 A national service program that placed adolescents outside their home community would reduce the ability of parents to perpetuate ideological separation through their choice of a community, as discussed in notes 155-56 and accompanying text, but also reduce parents' opportunity for ongoing influence over their children's development during this period. Imposing such duties on young adults, ages eighteen to twenty, would avoid burdening parental rights, but would more directly burden the exercise of the rights of the young adults.

181 Such an approach would restrict the costs associated with school disruption to those who have been most completely deprived of the benefits that flow from ideological integration. It would also represent a less dramatic departure from current compulsory education requirements, which generally only compel education to sixteen or seventeen years of age.

182 Note that this suggests that the holding in Yoder would be limited to a small windowstopping school earlier than eighth grade would, as the Court makes clear, raise serious concerns about the state's ability to meet its obligation to ensure all children receive the most basic reading, writing, and arithmetic skills, and extending the exemption beyond (roughly) the tenth grade would undermine the state's interest in facilitating unlike peer interactions. 
content, so long as those exemptions did not interfere with the state's ability to facilitate the profitable peer interactions.

Such an approach, however, while legally justifiable, might come at too great a cost-in educational disruption accompanying school shifts in the middle of high school, in costs associated with transporting children long distances to secure a sufficiently diverse student body, and in the symbolic effects associated with forcing parental compliance with educational programs they find so objectionable. In addition, compelling attendance could interfere with minors' exercise of their own educational choices, the sort of self-authored choicemaking the state's attendance requirements would be designed to promote. Indeed, although limiting parents' control over their children in late adolescence is not itself a radical move, shifting that control from parent to state would be unusual. The law begins to shift control over some decisions to minors over the course of adolescence, ${ }^{138}$ to reflect these adolescents' growing independence from their parents in acts and viewpoints.

- Less drastically, the state could encourage the desired peer interactions by eliminating supports, such as vouchers, for segregated alternatives in the late teenage years, or by subsidizing the pursuit of integrative interaction by individuals or institutions through tax benefits or other means. As noted, the state might also make the peer integration in public schools more attractive by affording parents more authority to make curriculum-specific adjustments. Religious conservatives, such as those who litigated in Mozert, are more likely to keep their children in public schools if they can exercise some control over the content of some of those interactions, ${ }^{184}$ and home-schooled children could get the benefit of some interaction with unlike peers if they were allowed to attend public school part time, or at least participate in after-school activities, such as sports. ${ }^{185}$ Excusing children from

183 In the abortion context, girls under eighteen have the right to obtain an abortion without their parent's notification or consent if they can establish their maturity, see Bellotti v Baird, 443 US 622 (1979), and some states shift control of minors' mental health treatment to the minor in mid-adolescence. See, for example, $50 \mathrm{~Pa}$ Stat Ann $\$ 7201$ (Purdon 1999). The constitutional protection of parental rights is never defined in age-specific terms. Indeed, the only minoritymajority line expressly drawn by the constitution is the requirement that individuals be eighteen to vote. See US Const Amend XXVI, \&1.

184 See Gutmann, Democratic Education at 110 (cited in note 62) (noting that mandatory sex education without an opt out would be unwise if it would "lead conservative parents to flee the public schools").

185 As noted above, some school districts have resisted inclusion of home-schooled children in school-day and after-school programs. Compare Swanson v Guthrie Independent School District No. I-1, 942 F Supp 511 (W D Okla 1996) (finding that school district's refusal to allow a home-schooled child to attend public school part time did not violate the parents' free exercise rights); Bradstreet v Sobol, 225 AD2d 175, 650 NYS2d 402 (1996) (upholding, against due process and equal protection challenges, state's authority to bar a home-schooled child from participation in school district's interscholastic sports program); Davis v Massachusetts Interscholastic 
classes and otherwise permitting curtailed participation might facilitate valuable interactions among peers, if handled appropriately, for such modifications could draw students' attention to the fact that some of their peers' families found the materials they were studying objectionable.

Of course, it will not be enough for the state to require or support public school attendance if families can select for religious and other forms of ideological homogeneity in their communities, and students can select for homogeneity in their choice of peer interactions. ${ }^{186}$ On both scores, we can learn a great deal by looking to the history of schools' attempts to integrate their educational programs along racial lines. White parents were able to prevent their children from interacting with African-American children by simply moving out of the racially integrated areas or by sending their children to racially segregated private schools, and attempts to thwart such actions by restructuring school authority and busing children long distances met with serious practical, political, and legal resistance. Similarly, within a school attended by both African-American and white students, segregation often continues, both because academic systems of tracking minimize class contact, and because students' selection of friends and larger social groupings reinforce the separation.

Policymakers are still struggling to find more successful ways of bringing students together across racial lines in the public schools and to ensure meaningful interaction among these racially unlike peers. ${ }^{187}$ The fact that securing the goal of racial integration has proved difficult, however, has not altered the view that the goal is an important one. Unless we determine that ideological integration, even in the late teenage years, is not an appropriate goal (a view I rely on the developmental literature to dispute), then the focus shifts from whether to integrate to how.

\section{CONCLUSION}

At the most basic level, the state's interest, like a parent's, is in preparing the child for a successful adulthood-successful in the eyes of society, the parent, and the (erstwhile) child. Success will surely in-

Athletic Association, 1995 Mass Super LEXIS 791 (enjoining athletic association and school district from excluding home-schooled child from athletic participation).

186 See Brown, Peer Groups and Peer Cultures at 180 (cited in note 128) (noting that adolescents, left to their own devices, will seek out peers who are similar to themselves).

187 Entwisle, Schools and the Adolescent at 213 (cited in note 79) (discussing the value of cooperative learning techniques, where children of mixed-race groups engage in noncompetitive problem solving, for improving achievement, self-esteem, and intergroup relations). These techniques were first championed by Gordon W. Allport in his seminal work, The Nature of Prejudice (Addison-Wesley 1954). 
clude the ability to engage in an occupation or otherwise support oneself, as well as the ability to participate responsibly in public activities, including the democratic process. Many theorists suggest that success should also be defined to include the ability to exercise independent judgment when making important life choices, a goal largely unaddressed in this context by the courts. Like the courts, however, the theorists shy away from giving the state any authority over the peer associations that are likely to facilitate the development of that choicemaking capacity. Driven, in my view, by an unsupported fear that interference with a parent's associational control of her child at any age will seriously interfere with the parent's ability to transmit important values and affiliations to the child, courts and theorists alike avoid any consideration of what benefit the state can confer upon children's identity development by providing them with an opportunity to interact with unlike peers.

The developmental literature offers a response to this fear on two levels. First, it suggests that any threat posed to parental control by children's exposure to unlike peers comes with considerable compensating developmental benefits to the individual child. Second, it suggests a possible means of achieving these benefits at minimal cost to the parent's control over the transmission of values and affiliations. While the developmental literature hardly holds all the answers, it suggests that courts and theorists alike have missed a big piece of children's developmental experience, which, when taken into account, demands a fresh look at how we strike the balance between parent and state in the battle over educational control. 


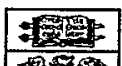

(4)

HeinOnline -- 67 U. Chi. L. Rev. 12902000 